\title{
Polysyncraton (Ascidiacea, Didemnidae): a re-examination of some specimens and descriptions of three new species
}

\author{
Livia M. OLIVEIRA ${ }^{1, *}$, Bert W. HOEKSEMA ${ }^{2} \&$ Rosana M. ROCHA $^{3}$ \\ ${ }^{1,3}$ Laboratório de Sistemática e Ecologia de Invertebrados Marinhos, Departamento de Zoologia, \\ Universidade Federal do Paraná, CP 19020, 81531-980 Curitiba, Brazil. \\ ${ }^{2}$ Department of Taxonomy and Systematics, Naturalis Biodiversity Center, P.O. Box 9517, \\ 2300 RA Leiden, the Netherlands. \\ *Corresponding author: liviaoliveira@ufpr.br \\ ${ }^{2}$ Email: bert.hoeksema@naturalis.nl \\ ${ }^{3}$ Email: rmrocha@ufpr.br \\ ${ }^{1}$ urn:1sid:zoobank.org:author:2058206A-50D4-4956-8888-358701793D7F \\ ${ }^{2}$ urn:lsid:zoobank.org:author:548DBAFD-040B-4773-A043-6FCC466160A1 \\ ${ }^{3}$ urn:1sid:zoobank.org:author:E170DE7A-DB70-4E5B-8488-45FA680812DA
}

\begin{abstract}
Polysyncraton Nott, 1892 is the second largest genus of didemnid ascidians; it has a wide distribution ranging from temperate to tropical waters. Seventy-one specimens of Polysyncraton from eight museum collections and recently collected samples were analyzed. This resulted in the description of three new species (P. cabofriense Oliveira \& Rocha sp. nov. from Brazil, P. globosum Oliveira \& Rocha sp. nov. from Australia and $P$. snelliusi Oliveira \& Rocha sp. nov. from Suriname) and emended descriptions of three further species (P. amethysteum (Van Name, 1902), P. magnilarvum (Millar, 1962) and $P$. purou C. Monniot \& F. Monniot, 1987).
\end{abstract}

Keywords. Ascidian, biodiversity, COI, taxonomy, Tunicata.

Oliveira L.M., Hoeksema B.W. \& Rocha R.M. 2019. Polysyncraton (Ascidiacea, Didemnidae): a re-examination of some specimens and descriptions of three new species. European Journal of Taxonomy 519: 1-25. https://doi.org/10.5852/ejt.2019.519

\section{Introduction}

Polysyncraton Nott, 1892 was originally established to accommodate two species, P. paradoxum Nott, 1892 and P. fuscum Nott, 1892. These species have four rows of stigmata, an atrial languet, many testis follicles and a spiral-shaped sperm duct. Sluiter (1909) was doubtful about the inclusion of undescribed species within Polysyncraton, due to the combination of characteristics observed, and suggested that the presence of the atrial languet should be excluded as a diagnostic feature of Polysyncraton in order to accommodate his new species. Hartmeyer (1912) also emphasized the large variation of characters among species within Polysyncraton, such as the presence or absence of an atrial languet, and characteristics shared with Didemnum Savigny, 1816, such as the number of testis follicles, and suggested that Polysyncraton should be re-examined. 
Currently, the genus is characterized by species with a large thorax, a large atrial languet, lateral thoracic organs usually located at the anterior region, more than three testis follicles (exceptionally three or less), five or less coils of the sperm duct and larvae that are usually large, gemmiparous and with more than six pairs of ectodermal ampullae (Monniot et al. 1991; Kott 2001). Although many morphological characteristics of Polysyncraton are similar to those of Didemnum, the unique combinations of characteristics shown by both genera allows their taxonomic separation. Moreover, a recent molecular study also suggested this separation, although the support of those clades was not strong (Oliveira et al. 2017).

The large number of species within Polysyncraton results in many species being differentiated by subtle morphological differences, which have not been described well in older literature. In an effort to complement the description of these species, many specimens (including types) from several localities around the world were re-examined and two new species were described, one from the Atlantic Ocean and one from Australia. Here we also describe a new species from recent collections in Brazil and another probably undescribed species that requires samples with larvae for a complete description.

\section{Material and methods}

A total of 71 samples representing 13 species of Polysyncraton was studied, some of them used for comparison (P. adelon Monniot F. \& Monniot C., 2001, P. horridum Monniot F. \& Monniot C., 2008, P. lacazei (Giard, 1872), P. louminae Monniot F., 1984 and P. trivolutum (Millar, 1960)). Those species are not included here because we did not find any further characters complementary to their original description.

Colonies in Polysyncraton can be slimy, soft or brittle in a gradient of spicule absence to high spicule density. In relation to surface texture, colonies can be smooth, reticulated or papillated in various arrangements (Monniot 1991; Kott 2001). There are usually many cloacas with a smooth or lobed rim. We used those characters in combination with zooid and larval characters to separate species. To obtain the spicules a piece of the colony $\left(25 \mathrm{~mm}^{2}\right)$ was incinerated under an ethanol lamp flame and put it in bleach for 5-10 min. to remove the remaining tissue. For colonies with a low density of spicules, a piece of the colony was boiled in bleach until the tissue had been completely digested. After rinsing in water two or three times, the spicules were then stored in an microtube containing $70 \%$ ethanol. A drop of spicules from the storage vial was poured on a small piece of copper tape fixed to a SEM stub and covered in Quick Carbon Coater SC-701C for analysis under a JEOL JSM-6480-LV scanning electron microscope at Naturalis Biodiversity Center, Leiden. Part of the samples were covered in gold and analyzed under a JEOL JSM-6360-LV at the Universidade Federal do Paraná.

For all colonies with a high density of spicules, hydrochloric acid $(\mathrm{HCl})$ was used to decalcify a small piece of the colony for easier dissection and study of zooids and larvae. Transverse sections of various thickness were cut from those pieces using a razor blade. The zooids and larvae were removed with microsurgery instruments under a Zeiss Discovery V8 MS-163 stereo microscope. They were stained with Harris hematoxylin and observed under a light microscope. The zooids and larvae were measured and photographed with a differential interference contrast (DIC) microscope (Zeiss Axio Scope) coupled to a camera (A1 AxioCam Mrc). Zooids and larval characters used to describe the species are illustrated in Fig. 1.

The large colony variation in the density of spicules and colouration in P. amethysteum (Van Name, 1902) pointed to the necessity of a molecular approach to better understand the limits of this variation. Total mitochondrial DNA was extracted from one piece of the colony $\left(1 \mathrm{~cm}^{2}\right)$ using Invitrogen ${ }^{\circledR}$ DNeasy \& Tissue Kit by Life Technologies following the standard protocol. PCR amplification reactions followed the Platinum taq DNA Polymerase protocol with slight modifications. The PCR protocol consisted of 
an initial denaturation step of $98^{\circ} \mathrm{C}$ for $30 \mathrm{~s}$, denaturation step of $98{ }^{\circ} \mathrm{C}$ for $5 \mathrm{~s}$ followed by 60 cycles with an annealing temperature step of $45^{\circ} \mathrm{C}$ for $5 \mathrm{~s}$, extension step of $72{ }^{\circ} \mathrm{C}$ for $15 \mathrm{~s}$, and a final extension step of $72^{\circ} \mathrm{C}$ for $5 \mathrm{~min}$. We used the tunicate-specific primers (Tun_for 5'-TCGACTAATCAT AAAGATATTAG-3' and Tun_rev2 3'-AACTTGTATTTAAATTACGATC- $\overline{5}$ ') designed by Stefaniak et al. (2009). The sequences are available from BOLD (Table 1).

The phylogenetic reconstruction is based on the Maximum Likelihood (ML) and Bayesian Inference (BI). The ML tree was generated using the RAxML-HPC2 on XSEDE (8.2.10) (Stamatakis 2014), under the GTRCAT model (Stamatakis 2006) and 1000 nonparametric bootstrap replications. BI was conducted using MrBayes on XSEDE (3.2.6) (Ronquist et al. 2012) with a model partitioned by codon position in the protein-coding gene. The BI analysis was performed with 10 million generations for each run, sampling trees every 1000 generations, using Markov Chain Monte Carlo (MCMC). The first $25 \%$ of generations were discarded as burn-in (2.5 million generations) before the calculation of the consensus tree. Both ML and BI analyses were run through CIPRES Science Gateway ver. 3.3. (Miller
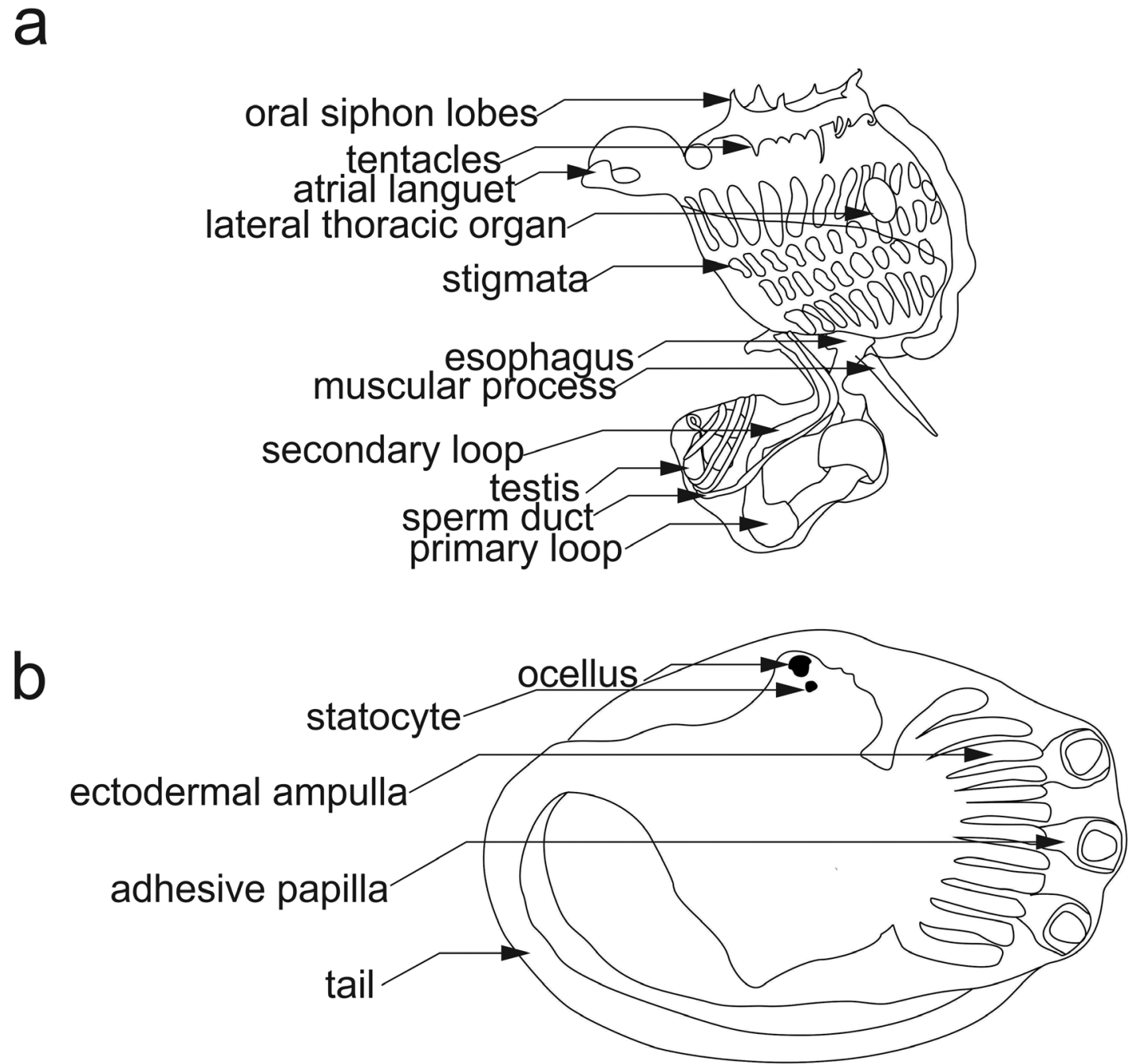

Fig. 1. Morphology of Polysyncraton. a. Zooid characters. b. Larval characters. 
Table 1. Accession numbers of the specimens, sequences IDs and the localities where the samples were collected.

\begin{tabular}{|c|c|c|c|c|}
\hline Species & $\begin{array}{c}\text { Genbank } \\
\text { accession } \\
\text { number }\end{array}$ & $\begin{array}{c}\text { BOLD } \\
\text { accession } \\
\text { number }\end{array}$ & Locality & Source \\
\hline Polysyncraton amethysteum & & UPDID089-17 & Paraíba, PB, Brazil & this study \\
\hline P. amethysteum & & UPDID090-17 & Santa Catarina, SC, Brazil & this study \\
\hline P. amethysteum & & UPDID091-17 & Espírito Santo, ES, Brazil & this study \\
\hline P. amethysteum & & UPDID092-17 & Espírito Santo, ES, Brazil & this study \\
\hline P. amethysteum & & UPDID093-17 & Paraíba, PB, Brazil & this study \\
\hline P. amethysteum & & UPDID094-17 & Paraná, PR, Brazil & this study \\
\hline P. amethysteum & & UPDID159-18 & Bocas del Toro, Panama & this study \\
\hline Polysyncraton sp. & KU221186.1 & & Espírito Santo, ES, Brazil & Oliveira et al. (2017) \\
\hline Polysyncraton sp. & KU221187.1 & & Ceará, CE, Brazil & Oliveira et al. (2017) \\
\hline Polysyncraton lacazei & AY600986.1 & & Mediterranean Sea, Spain & Turon \& López-Legentil (2004) \\
\hline Polysyncraton poro & KU221217.1 & & Moorea, French Polynesia & Oliveira et al. (2017) \\
\hline Polysyncraton poro & KU221222.1 & & Moorea, French Polynesia & Oliveira et al. (2017) \\
\hline Polysyncraton sp. & & UPDID096-17 & Rio de Janeiro, RJ, Brazil & this study \\
\hline Cystodytes dellechiajei & AY523076.1 & & Mediterranean Sea, Spain & Turon \& López-Legentil (2004) \\
\hline
\end{tabular}

et al. 2010). The figure of the recovered phylogenetic tree (Fig. 5) was made using FigTree 1.4.2 (Rambaut 2014).

\section{Institutional abbreviations}

AMNH $=$ American Museum of Natural History, New York, USA

DZUP = Ascidiacea Collection of the Departamento de Zoologia, Universidade Federal do Paraná, Curitiba, Brazil

LIPY = Tunicata Collection of Laboratório de Invertebrados Marinhos Paulo Young, Universidade Federal da Paraíba, João Pessoa, Brazil

MNHN = Muséum national d'Histoire naturelle, Paris, France

$\mathrm{NHM}=$ Natural History Museum, London

$\mathrm{UF}=$ Florida Museum of Natural History, University of Florida, Gainesville, FL, USA

USNM = National Museum of Natural History, Smithsonian Institution, Washington DC, USA

ZMA = Zoölogisch Museum of Amsterdam, now part of Naturalis Biodiversity Center, Leiden, the Netherlands

\section{Results}

Class Ascidiacea Blainville, 1824

Order Aplousobranchia Lahille, 1886

Family Didemnidae Giard, 1872

Genus Polysyncraton Nott, 1892

Polysyncraton amethysteum (Van Name, 1902)

Figs 2-5

Polysyncraton amethysteum Van Name 1902: 366, pl. 54, figs 62, 64-67.

Polysyncraton amethysteum - Rodrigues 1962: 195. - Millar 1977: 200, fig. 21. — Rocha et al. 2005: 467. — Lotufo \& Silva 2006: 228. — F. Monniot 2016: 207, fig. 4D. 
OLIVEIRA L.M. et al., Re-examination of specimens and three new species of Polysyncraton

Didemnum (Polysyncraton) amethysteum - Van Name 1921: 333, figs 27-29; 1945: 95, fig. 41, pl. 18, fig. 3. — Moure et al. 1954: 236. — Millar 1958: 499.

\section{Material examined}

Paratype

BERMUDA • 1 colony; NHM 1914.5.18.103.

\section{Other material}

BRAZIL - Paraíba - 4 colonies; Barra de Camaratuba; 06²36'12" S, 345' $51^{\prime \prime}$ W; 0-0.3 m depth; 13 Mar. 2013; L.M. Oliveira leg.; intertidal zone; DZUP POSC-23 to DZUP POSC-25, LIPY UFPB TUN-395, slides DZUP DID5.30 to DID5.31 - 1 colony; same collecting data as for preceding but 6 May 2008; Projeto Biota Paraíba leg.; intertidal zone; LIPY UFPB TUN-230 • 4 colonies; Baia da Traição, 06 $41^{\prime} 15^{\prime \prime}$ S, 34 $55^{\prime} 50^{\prime \prime}$ W; 0-0.3 m depth; 12 Mar 2013; L.M. Oliveira leg.; intertidal zone; DZUP POSC-13 to POSC-14, slides DZUP DID5.13 to DID5.14 - 3 colonies; Quebramar Cabedelo; $06^{\circ} 57^{\prime} 42^{\prime \prime} \mathrm{S}, 34^{\circ} 50^{\prime} 34^{\prime \prime} \mathrm{W}$; 0-0.5 m depth; 25 Mar. 2013; L.M. Oliveira leg.; intertidal zone; DZUP

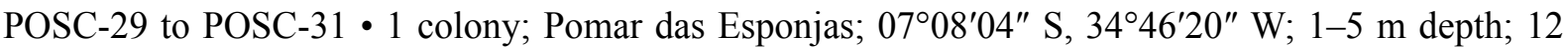
Jan. 2009; Projeto Biota Paraíba leg.; snorkeling; LIPY UFPB TUN-176 2 colonies; Ponta do Cabo Branco; 07 $08^{\prime} 50^{\prime \prime}$ S, 34 $47^{\circ} 51^{\prime \prime}$ W; 0-0.3 m depth; 28 Mar. 2013; L.M. Oliveira and R.M. Rocha leg.; intertidal zone; DZUP POSC-15 to POSC-16, slides DZUP DID5.15 to DID5.16 4 colonies; Praia

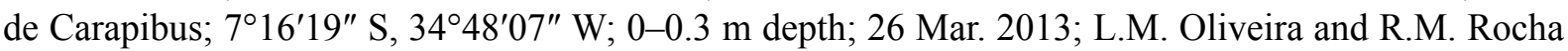
leg.; intertidal zone; DZUP POSC-26 to DZUP POSC-28, LIPY UFPB TUN-396 5 colonies; Praia de Coqueirinho; $07^{\circ} 16^{\prime} 19^{\prime \prime}$ S, 34 $48^{\circ} 07^{\prime \prime}$ W; 0-0.3 m depth; 27 Mar. 2013; L.M. Oliveira and R.M. Rocha leg.; intertidal zone; DZUP POSC-18 to POSC-22 3 colonies; same collecting data as for preceding but 3 Jun. 2008; Projeto Biota Paraíba leg.; intertidal zone; LIPY UFPB TUN-153, LIPY UFPB TUN-156. Pernambuco • 1 colony; Goiana, Pontas de Pedras; 07³7'17" S, 34²48'15" W; 13 Dec. 2013, J. Nogueira leg.; intertidal zone; DZUP POSC-045. - Espírito Santo - 2 colonies; Carapebus; 20 13"46.02" S, $40^{\circ} 12^{\prime} 12.67 "$ W; 0-0.3 m depth; 24 Jan 2012; G.A. Gamba leg.; intertidal zone; DZUP POSC-055, slide DZUP DID5.06 • 3 colonies; Aracruz, Santa Cruz; 2001'53.12" S, 4009'29.22" W; 0-0.3 m depth; 25 Jan. 2012; G.A. Gamba leg.; intertidal zone; DZUP POSC-056 to POSC-057, DZUP POSC-059, slides DZUP DID5.07 to DID5.08, DZUP DID5.10.

GHANA: 7 colonies; Elmira Gold Coast; 11 Oct. 1938; F.R. Irvine and V.G. Foote leg.; NHM 1959.5.27.23, NHM 1959.5.27.24 • 1 colony; Elmira Gold Coast; 28 Dec. 1932, E.D. Plumptre leg.; NHM 1937.1.5.1.

PUERTO RICO • 1 colony; 10 Jul 1915; AMNH 797 • 1 colony; 30 Jun 1915; AMNH 798.

UNITED STATES - Florida • several colonies; Atlantic side, Biscayne Bay, banks near Soldiers Keys; 3 Mar. 1916; W.G Van Name leg.; AMNH 314 - 2 colonies; Gulf of Mexico, St. Teresa, seagrass beds; 29 53'41.3" N, 84³3'23.4" W; 2 m depth; 7 Nov 2011; sand; UF 1127 • 1 colony; Gulf of Mexico, north of St. Petersburg; $29^{\circ} 01^{\prime} 40.8^{\prime \prime} \mathrm{N}, 8^{\circ} 35^{\prime} 19.3^{\prime \prime} \mathrm{W}$; 18-20 m depth; 12 Mar 2011; G. Paulay, M. Bemis and N. Evans leg.; UF 1037 • 5 colonies; Gulf of Mexico, Hudson; 28 $21^{\circ} 05.4^{\prime \prime}$ N, 8255'04.8" W; 6 m depth; 2 May 2011; G. Paulay leg.; UF 1749, slide DZUP DID5.09 • 1 colony; Gulf of Mexico, Dry Tortugas, $\mathrm{n}^{\circ} 23$; 10 Jun. 1931; Tandy-Colman leg.; NHM 1931.12.25.2 • 1 colony; Gulf of Mexico, off Florida; 26¹6'49" N, 8244'01" W; 30.4 m depth; 19 Jul. 1981; USNM 17364.

\section{Emended description}

The specimen in NHM 1914.5.18.103 (Bermuda) has not been dissected because of the small size of the colony. It has a gelatinous and transparent tunic, without spicules, through which zooids could be seen on the colony surface without a pattern of organization. The specimen from the Atlantic coast of 
Florida (AMNH 314) has a brownish colour, is also small ( $3 \mathrm{~cm}$ in diameter and $1 \mathrm{~mm}$ thick), with several cloacal apertures and a spicule layer on the colony surface. The zooids are brownish and the atrial languet is bifurcated. The lateral thoracic organ is circular and protruding at the level of the $2^{\text {nd }}$ row of stigmata. The abdomen has a glandular tissue. The testis has three follicles surrounded by four coils of the sperm duct. Other specimens from the Gulf of Mexico (USNM 17364; Fig. 2; UF 1037, UF 1127 and UF 1749) have an atrial languet with a flat tip rather than bifurcated and testis with four follicles surrounded by five coils of the sperm duct. The glandular tissue in the abdomen has not been observed. Larvae were found in sample UF 1749 only. They look like those found in the specimens from São Paulo, Brazil. The specimens from Puerto Rico (AMNH 797 and AMNH 798) are similar in spicule density and zooid morphology to the samples from the Gulf of Mexico.

The colonies from Ghana (NHM 1959.5.27.23-24) are less than $3 \mathrm{~cm}$ in diameter. In contrast with the information given about this sample by Millar (1953), the larval trunk is $0.8 \mathrm{~mm}$ long. The colonies are pinkish-purple, gelatinous, the colony surface is smooth, shiny and marked with a spicule accumulation around the oral siphons. The zooids are $0.8-1.0 \mathrm{~mm}$ long. The oral siphon has six short triangular lobes. The atrial aperture is small. The atrial languet is bifurcated, sometimes with a flat tip. The lateral thoracic
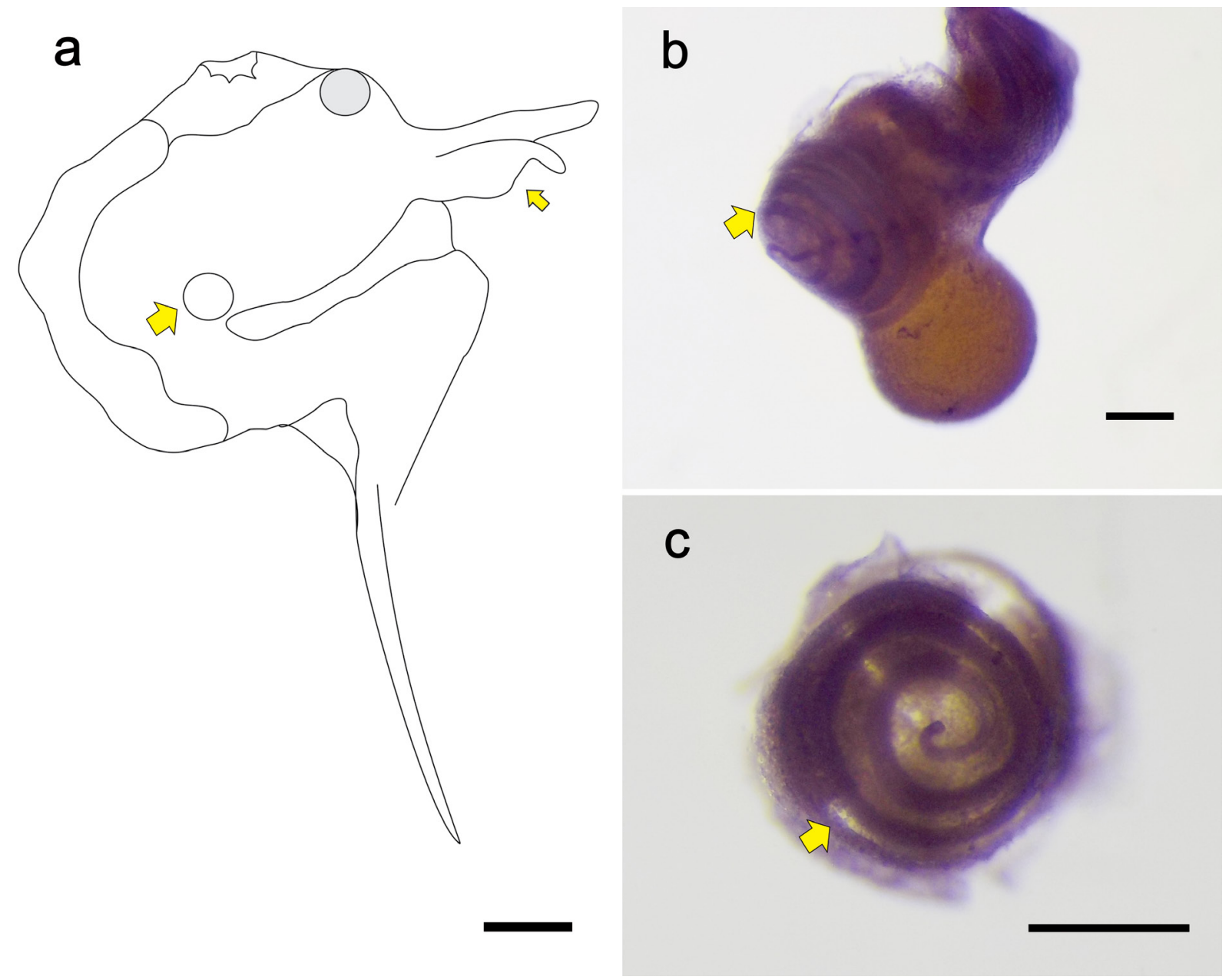

Fig. 2. Polysyncraton amethysteum (Van Name, 1902), Florida (USNM 17364). a. Thorax with bifurcated atrial languet (small arrow) and thoracic organ (big arrow). b. Stained abdomen, sperm duct with five coils (arrow). c. Detail of the testis with four follicles and sperm duct with four coils (arrow). Scale bars: $0.1 \mathrm{~mm}$. 

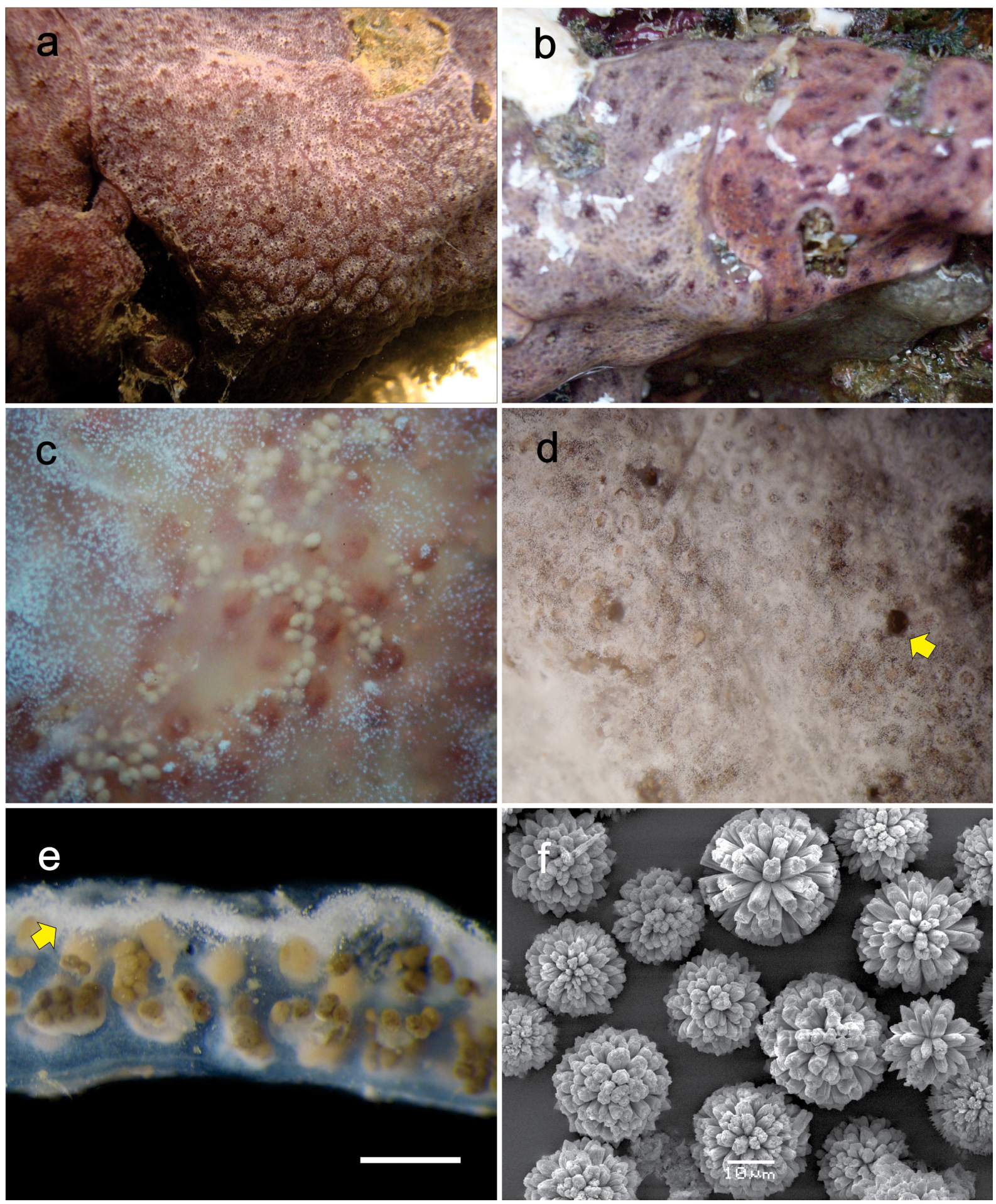

Fig. 3. Polysyncraton amethysteum (Van Name, 1902), Paraíba, Brazil. a-b. Colonies in situ. c-d. Colony surface detail (arrow indicates one cloacal aperture) (DZUP POSC-14 and DZUP POSC13, respectively). e. Cross section of the colony, with thin layer of spicules (arrow) (DZUP POSC-14). f. Spicules. Scale bars: $\mathrm{e}=1 \mathrm{~mm} ; \mathrm{f}=10 \mu \mathrm{m}$. 

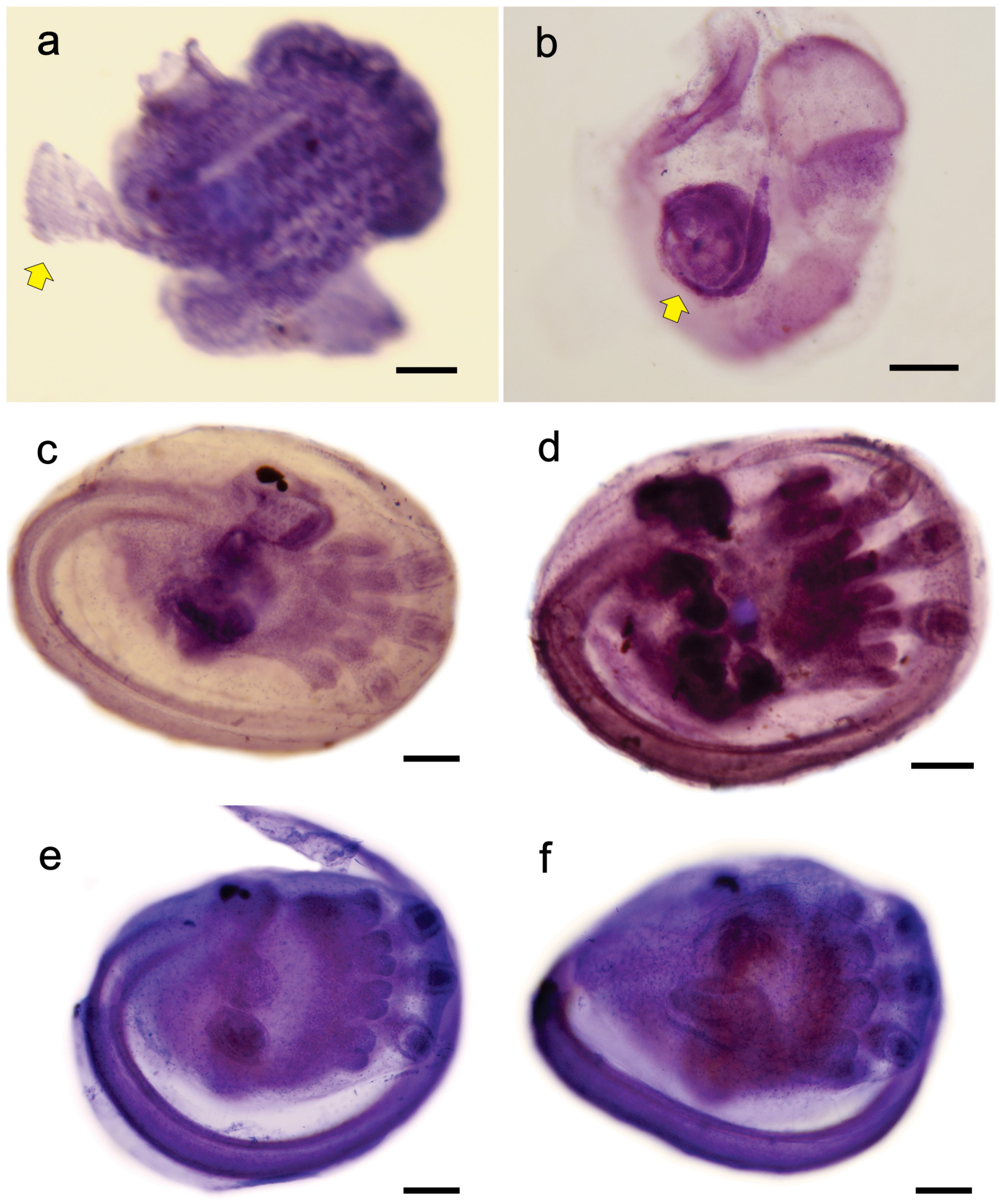

Fig. 4. Polysyncraton amethysteum (Van Name, 1902), Brazil (DZUP DID-034, POSC-016; LIPY UFPB TUN-293). Structures stained with hemalum. a. Thorax, atrial languet (arrow). b. Abdomen showing the position of the testis (arrow). c-f. Larvae in Brazilian specimens from São Paulo (c) and Paraíba (d-f), different stages in the same colony (e-f). Scale bars: $0.1 \mathrm{~mm}$. 
organs are circular, not protruding and located in the anterior region of the thorax at the level of the $2^{\text {nd }}$ row of stigmata, close to the atrial aperture. The pharynx has six stigmata per half row. The abdomen is positioned horizontally in relation to the thorax. The secondary gut loop overlays the stomach. The testis is divided in five follicles surrounded by three coils of the sperm duct. The larvae are present on the colony surface. They are elliptical, gemmiparous, uncoloured, trunk measuring $0.8-1.0 \mathrm{~mm}$. A tail with a diameter of $35 \mu \mathrm{m}$ winds about halfway around the trunk. Three adhesive papillae are close together. The sucker of the central adhesive papilla is $100 \mu \mathrm{m}$ in diameter. There are six elongated ectodermal ampullae on each side. The sensorial vesicle lays in the posterior region of the larval trunk. The ocellus is $40 \mu \mathrm{m}$ long. The distance between ocellus and anterior region of the tail is $200 \mu \mathrm{m}$. Larva with two embryos: oozoid dorsal and blastozooid ventral.

The morphological characteristics of the zooids of the Brazilian specimens are very similar to those observed by Van Name (1902), although the variation in colony colour and spicule density is much larger in Brazil. The colour varies from purple to brick. The colonies are 3 to $10 \mathrm{~cm}$ in diameter and 1 to $3 \mathrm{~mm}$ thick (Fig. 3). The atrial languet can be bifurcated or with a flat tip. The pharynx has seven to nine stigmata per half row. The lateral thoracic organ is circular and protruding at the level of the $2^{\text {nd }}$ row of stigmata. The testis has three to five follicles (even in zooids of the same colony), surrounded by three to five coils of the sperm duct. The larva is gemmiparous, with a trunk that is 0.8 to $1.0 \mathrm{~mm}$ long. A tail 85 to $90 \mu \mathrm{m}$ wide winds about three-quarters of the way around the trunk. The peduncles of the adhesive papillae are long, while the sucker of the central adhesive papilla is 63 to $80 \mu \mathrm{m}$ in diameter. There are six or eight pairs of ectodermal ampullae, but four pairs in different stages of duplication were seen in immature larvae (Fig. 4c-f). The sensorial vesicle is in the mid or posterior dorsal region of the larval trunk. The ocellus is 56 to $60 \mu \mathrm{m}$ long. The distance between the ocellus and the anterior region of the tail is 185 to $238 \mu \mathrm{m}$. The pharynx of the oozooid has $8,7,6,6$ stigmata on each half row.

\section{Remarks}

Lotufo (2002) claimed that Brazilian specimensof this species differ from the ones described by Van Name (1902) in the different arrangement of spicules and in the single cloaca per colony. However,

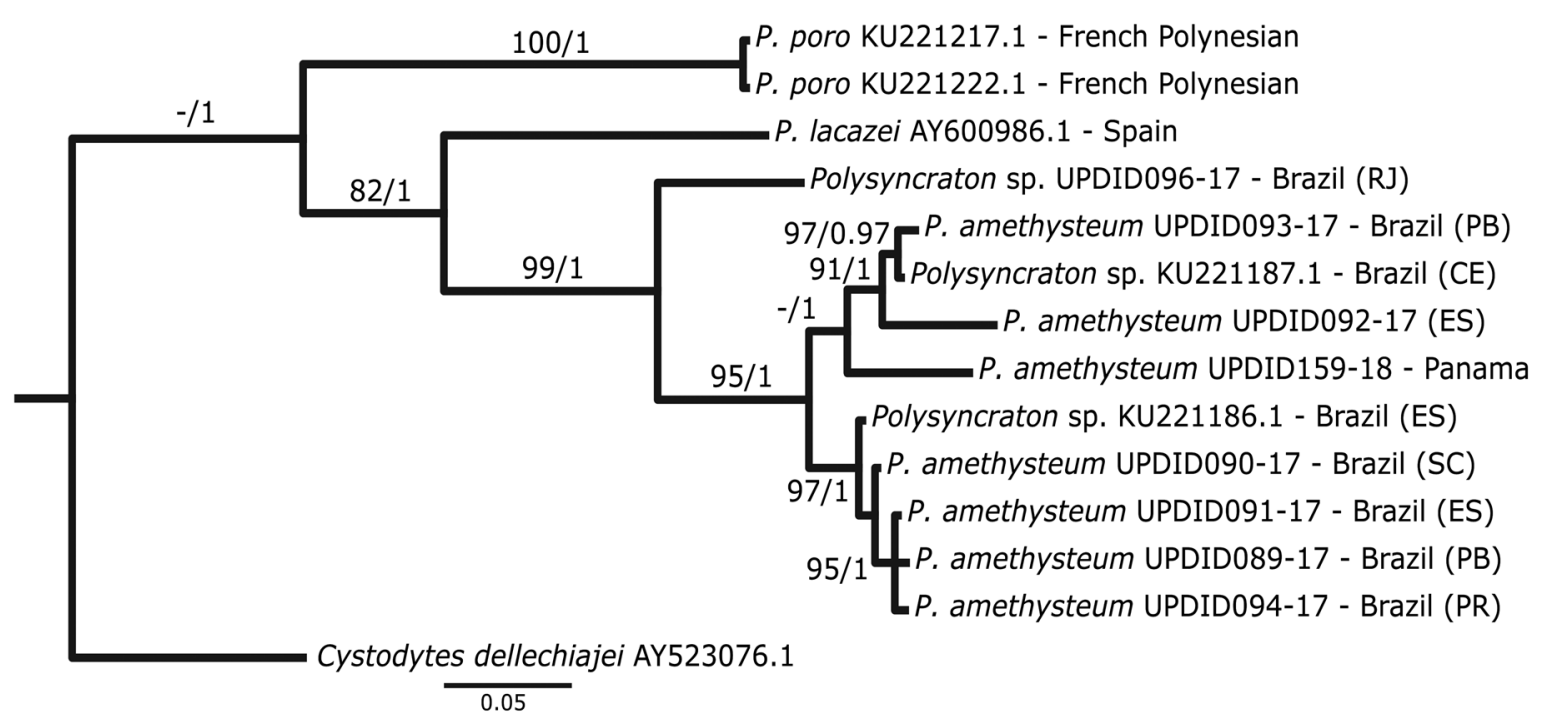

Fig. 5. Maximum likelihood tree of species of Polysyncraton based on analysis of 16 sequences of mitochondrial COI. Numbers on or below branches represent the support value of the bootstrap for Maximum likelihood $(>70 \%)$ and posterior Bayesian probabilities ( $>0.97)$. Abbreviations of Brazilian states are explained in Table 1. 
the colonies studied by us showed a huge variation in colour, spicule density and cloaca number as also observed by Pérès (1949) and Millar (1953) in African specimens. Lotufo (2002) also mentioned having studied a sample from the type series deposited in the American Museum of Natural History, with very large larvae (1.5 mm trunk length), but we were not able to find and examine this sample in the museum collection. The only sample close to the type locality with available larvae was one from Florida (UF1749), with larvae whose trunk varies from $0.8 \mathrm{~mm}$ to $1.2 \mathrm{~mm}$ within the same colony. F. Monniot (2016) compared specimens from French Guiana with those from Bermuda and concluded that they belonged to the same species.

Molecular analyses (ML and IB) also suggest the existence of only one valid species. Samples from Panama to south Brazil grouped in one clade, corresponding to P. amethysteum with a significant bootstrap value $(95 \%)$ and posterior probability support $(\mathrm{IB}=1)$ (Fig. 5). Although this clade seems to be split in two branches, one of them does not have enough bootstrap support. The intraspecific genetic divergence (p-distance) among haplotypes ranged from 0.7 to $9.8 \%$, while the interspecific divergence with P. lacazei was $\sim 22 \%$, and with P. poro was $\sim 27 \%$. Based on genetic evidence and the lack of clear morphological separation in the samples examined, we consider that they all belong to $P$. amethysteum, a species with a large phenotypic variation.

The haplotype UPDID096-17 from Rio de Janeiro, in contrast, is a different species with 12.4 to $14.9 \%$ distance from P. amethysteum, and will be commented on later (Polysyncraton sp.).

\section{Distribution}

Type locality: Bermuda (Van Name 1902). Other localities: United States - Florida (Van Name 1945), Puerto Rico, Cuba, Belize (Goodbody 2000; Van Name 1945), Guadeloupe, Martinique (Gravier 1955), Panama (this study), Colombia (Van Name 1945), French Guiana (F. Monniot 2016), Brazil - Ceará to Santa Catarina (Millar 1977; Lotufo 2002; Rocha et al. 2012), Cape Verde, Senegal, Ghana (Pérès 1948; Millar 1953; C. Monniot \& F. Monniot 1967).

Polysyncraton cabofriense Oliveira \& Rocha sp. nov. urn:1sid:zoobank.org:act:356E2138-BAED-47B4-8E06-8182B064EB7B

Fig. 6

\section{Etymology}

The name refers to the region where the species was found.

\section{Material examined}

\section{Holotype}

BRAZIL - 1 colony; Rio de Janeiro, Cabo Frio, Pargos Island, Enseada do Pinguim; $22^{\circ} 51^{\prime} 10^{\prime \prime}$ S, 4154'22" W; 10 m depth; 7 May 2014; L.F. Skinner leg.; scuba; DZUP POSC-50, slide DZUP DID5.02.

\section{Paratypes}

BRAZIL -2 colonies; same collecting data as for holotype; DZUP POSC-46, DZUP POSC-49, slide DZUP DID5.05 • 2 colonies; Comprida Island, Ponta Leste; $22^{\circ} 51^{\prime} 41^{\prime \prime} \mathrm{S}, 41^{\circ} 56^{\prime} 12^{\prime \prime} \mathrm{W} ; \sim 8 \mathrm{~m}$ depth; 6 May 2014; L.F. Skinner leg.; DZUP POSC-47, DZUP POSC-48, slides DZUP DID5.03, DZUP DID5.04.

\section{Description}

Living colonies are yellowish, with a diameter of 3 to $15 \mathrm{~cm}$ and a thickness of 2 to $3 \mathrm{~mm}$. When preserved in formalin, colonies usually lose their colour and become cream coloured, sometimes white. They have 

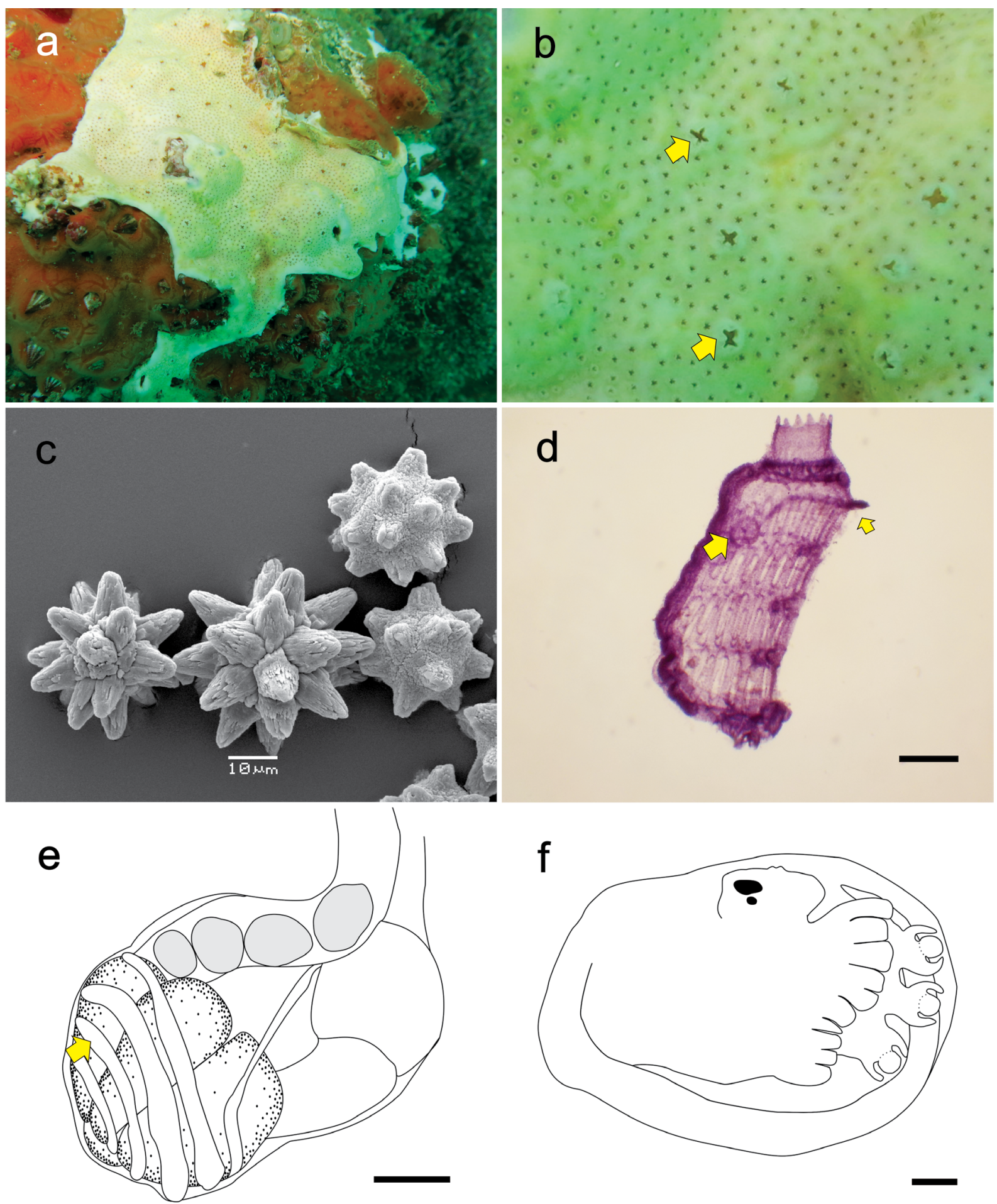

Fig. 6. Polysyncraton cabofriense Oliveira \& Rocha sp. nov. (DZUP POSC-50). a. Colony in situ. b. Colony surface (arrows indicating common cloacal apertures with lobes). c. Spicules. d. Thorax stained (big arrow indicating the lateral thoracic organ and small arrow the atrial languet). e. Abdomen (arrow indicating the sperm duct coil). f. Larva. Scale bars: $\mathrm{d}-\mathrm{f}=0.1 \mathrm{~mm}$. Photo (a) courtesy of L.S. Skinner. 
an irregular shape, molding themselves to the substrate. The colony surface has several common cloacal apertures, each one with short lobes (Fig. 6a-b). The tunic is firm, brittle and smooth. Green algae were observed on the surface of some colonies. Spicules are distributed in the whole tunic, with relatively high concentrations on each side of the thorax at the level of the lateral thoracic organ. There are two kinds of spicules: stellate, 32 to $40 \mu \mathrm{m}$ in diameter, with 6 or 7 blunt-tipped conical rays in transverse optical section; others are smaller ( 25 to $28 \mu \mathrm{m}$ in diameter), with round and short rays (Fig. 6c).

Zooids are 0.8 to $1.0 \mathrm{~mm}$ long. The oral siphon has six small triangular lobes. The atrial aperture is wide, exposing most of the pharynx. The atrial languet is pointed and thin (Fig. 6d) or wide and rounded. In some specimens it was absent, probably lost during dissection. The lateral thoracic organs are circular, not protruding and localised between the first and second rows of stigmata on the border of the atrial aperture. The pharynx has seven stigmata in the first two half rows and six stigmata on the posterior two half rows. The muscular process is lacking. The testis is divided in three oval follicles surrounded by three coils of the sperm duct. The oocyte is single, measuring $0.6 \mathrm{~mm}$.

The larvae are elliptical, gemmiparous, the trunk measuring 0.9 to $1.0 \mathrm{~mm}$. A tail with a diameter of $95 \mu \mathrm{m}$ winds about $3 / 4$ of a turn around the trunk. The three adhesive papillae show a short and wide peduncle. The sucker of the central adhesive papilla is $124 \mu \mathrm{m}$ in diameter. There are 10 pairs of rounded ectodermal ampullae. The ocellus is $45 \mu \mathrm{m}$ long and $346 \mu \mathrm{m}$ distant from the anterior region of the tail.

\section{Remarks}

Only two species of Polysyncraton have been reported from Brazil, P. amethysteum with a distribution along the whole coastline and P. maurizelae Paiva et al., 2015 from Rocas Atoll (Paiva et al. 2015). Polysyncraton cabofriense sp. nov. differs from P. amethysteum by its colour, higher density of spicules, lobed cloaca and larvae with more pairs of ectodermal ampullae. Polysyncraton maurizeliae has orange colonies with smooth common cloacal apertures, zooids longer and with 12 stigmata in the $1^{\text {st }}$ row, and the lateral thoracic organ in the $3^{\text {rd }}$ row. Among other species from the Atlantic, P. louminae F. Monniot, 1984 has a colony of similar shape and spicules, but the colony is grey, zooids have longer oral siphons and two testis follicles surrounded by 3 to 5 coils of the sperm duct, and the larvae are not gemmiparous and have more pairs of ectodermal ampullae (F. Monniot 1984).

\section{Distribution}

Type locality: Brazil (Rio de Janeiro).

Polysyncraton globosum Oliveira \& Rocha sp. nov. urn:1sid:zoobank.org:act:1BF4A55D-4A94-4598-8BC0-4A26E33EF5DD

Fig. 7

Didemnum (Polysyncraton) magnetae - Millar 1963: 702 (misidentification, not Hastings, 1931).

\section{Etymology}

The name refers to the shape of the colony.

\section{Material examined}

\section{Holotype}

AUSTRALIA • 1 colony; Bowerbank leg.; NHM 1866.3.21.21, slides NHM 1866.3.21.21, DZUP DID 5.12 .

\section{Paratype}

AUSTRALIA • 1 colony; Bowerbank leg.; NHM 1866.3.21.20, slide NHM 1866.3.21.20. 

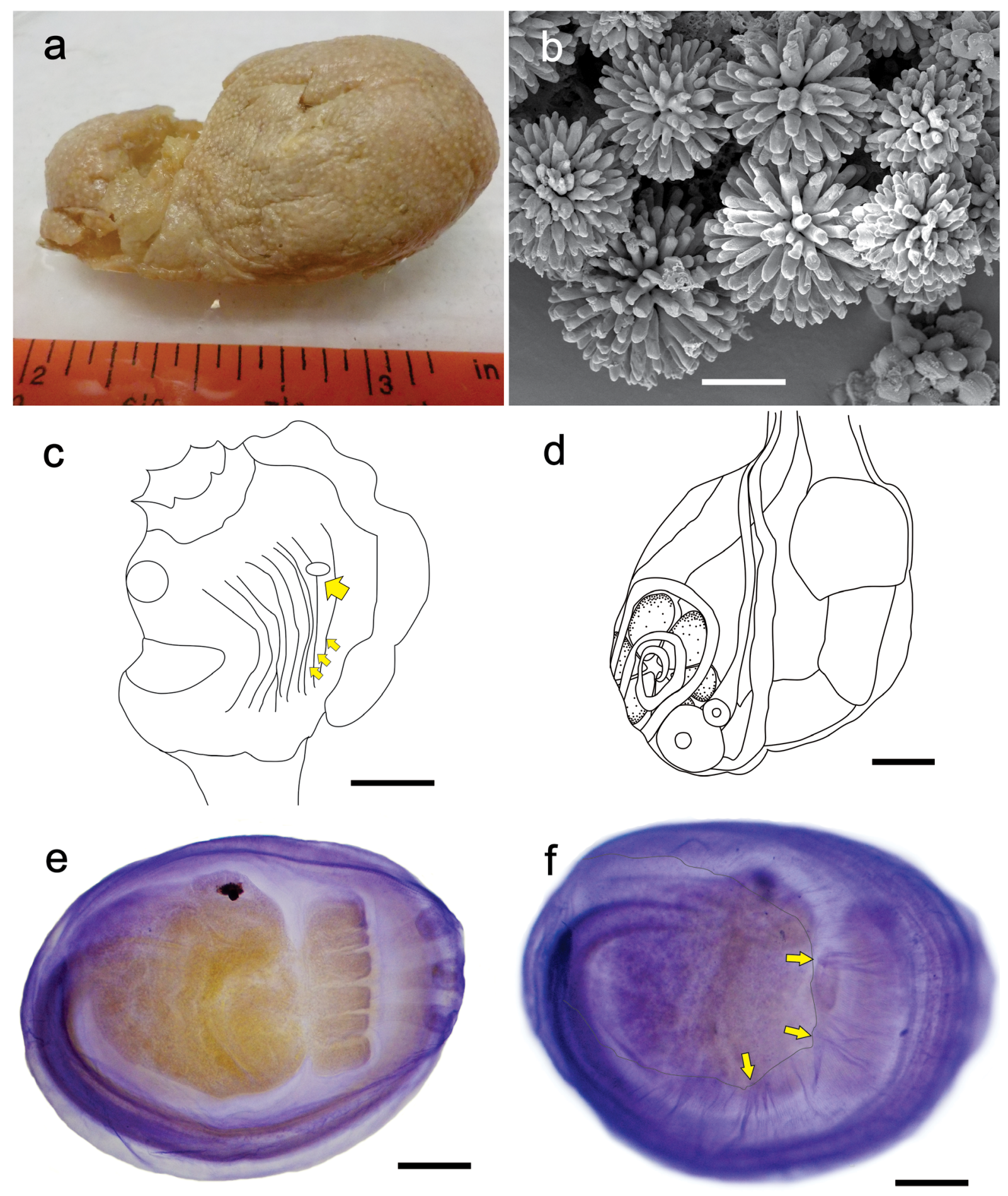

Fig. 7. Polysyncraton globosum Oliveira \& Rocha sp. nov., Australia (NHM 1866.3.21.21). a. Preserved colony. b. Spicules. c. Thorax (big arrow indicates the lateral thoracic organ and small arrows the muscle fibers present on each side of the thorax). d. Abdomen. e-f. Larva stained with hemalum (the arrows in $\mathrm{f}$ indicate the membrane of the tail). Scale bars: $\mathrm{b}=10 \mu \mathrm{m} ; \mathrm{c}-\mathrm{d}=0.1 \mathrm{~mm}$; $-\mathrm{f}=0.2 \mathrm{~mm}$. 


\section{Description}

The species is characterised by its globular colonies, $3.5 \mathrm{~cm}$ at maximum length (Fig. 7a). The tunic is gelatinous and the colony surface is smooth. The spicules are distributed in low density, mainly on the colony surface. Just one cloacal aperture with a smooth edge was observed in each colony. The globular spicules are 20 to $30 \mu \mathrm{m}$ in diameter and have numerous thin rays (16 to 18 rays in optical transverse section) (Fig. 7b).

The thorax has 12 conspicuous muscle bundles on each side (Fig. 7c). The oral siphon has six triangular lobes. The atrial languet is bifurcated but was lost in some thoraces when the zooids were dissected. The lateral thoracic organ is circular, not protruding, located at the level of the $1^{\text {st }}$ row of stigmata, in the middle of the thorax (Fig. 7c). The second gut loop does not overlay the stomach. The testis is divided in six follicles surrounded by two or three coils of the sperm duct (Fig. 7d), although the description by Millar (1963) mentioned up to eight follicles. Larvae are elliptical, the trunk 1.0 to $1.3 \mathrm{~mm}$ long (Fig. 7e). The tail winds about $3 / 4$ of the way around the trunk. At the left side of the larva, it is possible to see a wide membrane projecting from the sides of the tail (Fig. 7f). The three adhesive papillae with long and thin peduncles are close together and there are eight pairs of rectangular ectodermal ampullae. The
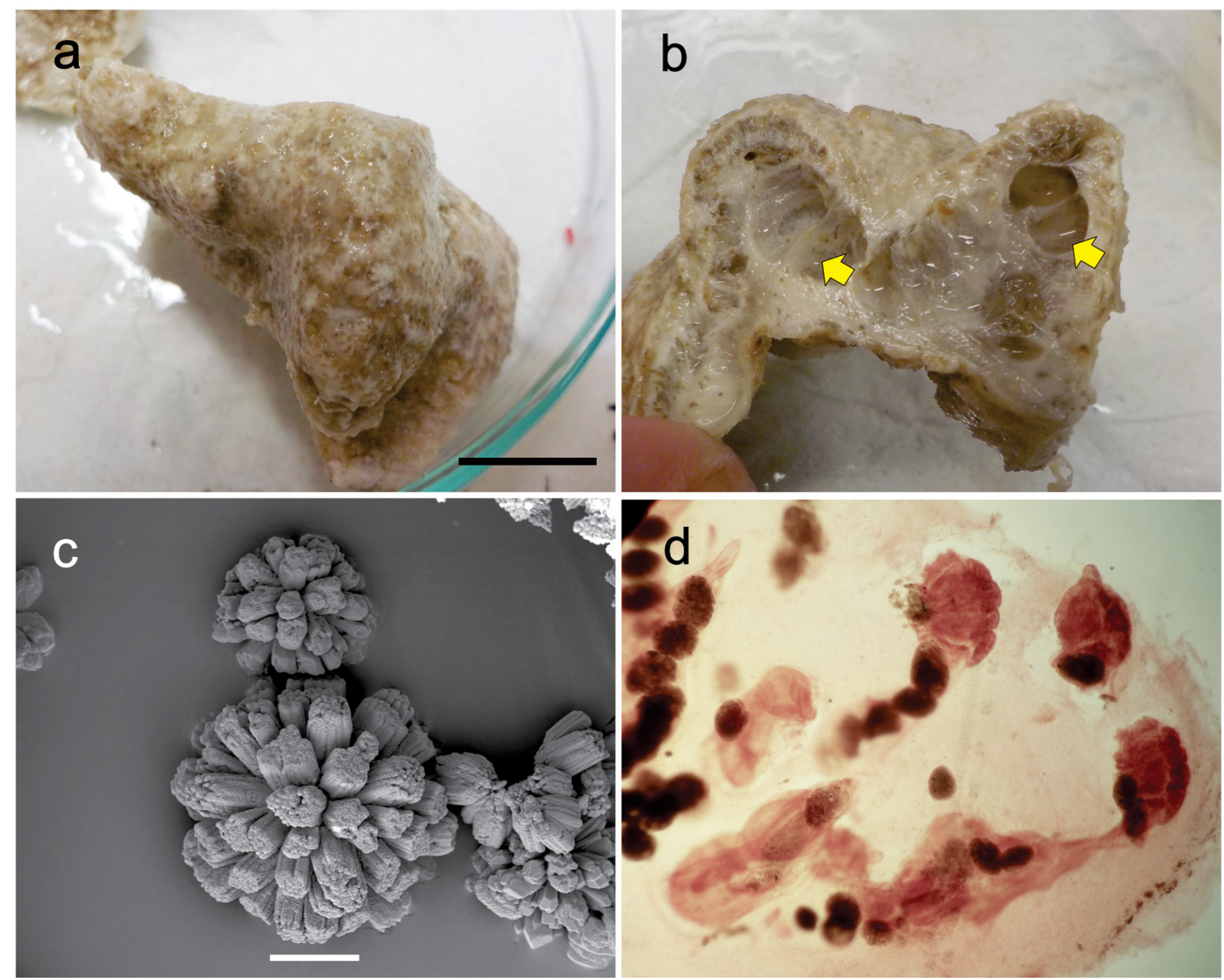

Fig. 8. Polysyncraton magnetae Hastings, 1931, type specimen (NHM 1930.12.17.46). a. Preserved colony. b. Cross section of the colony showing cavities found in the median region (arrows). c. Spicules. d. Cross section of a decalcified colony. Scale bars: $\mathrm{a}=1 \mathrm{~cm} ; \mathrm{c}=10 \mu \mathrm{m}$. 
sensory vesicle is in the central region of the larval trunk, with the ocellus and estatocyte close together. The larva is not gemmiparous.

\section{Remarks}

These Australian specimens, which were deposited at the Natural History Museum in London, have previously been identified as P. magnetae Hastings, 1931 by Millar (1963). The sample NHM 1930.12.17.46 from the Great Barrier Reef, Stat. XXIII, R/V "Magneta", collected on 12 Mar. 1929 is part of the type series of P. magnetae and was re-examined (Fig. 8). Although also looking globular, the colony is not as solid as in $P$. globosum sp. nov. and has a high density of spicules in the tunic, with cylindrical rays of a larger diameter and in a smaller number than in P. globulosum (Fig. 8). The atrial languet in $P$. magnetae is almost imperceptible, short and pointed, and could be missed during dissection, although Hastings (1931) described it as large. Unfortunately, the larva of P. magnetae is not known for comparison with congeneric species. Kott (2001) also realised that Millar's identification was wrong and suggested that the NHM material belonged to P. meandratum F. Monniot, 1993. We do not agree with this suggestion because $P$. meandratum has thin and sheet-like colonies, an atrial languet larger than those observed in P. globosum sp. nov., less male follicles and a larva less than half the size of that of P. globosum sp. nov. (F. Monniot 1993).

\section{Distribution}

Type locality: Australia (Millar 1963).

Polysyncraton magnilarvum (Millar, 1962)

Fig. 9

Didemnum (Polysyncraton) magnilarvum Millar, 1962: 165, fig. 25.

\section{Material examined}

MADAGASCAR - 3 slides; South Madagascar, further collecting data unknown; MNHN A2-2466, MNHN A2-2767, MNHN A2-2470.

\section{Emended description}

The specimen from Magadascar has a long and trifurcated atrial languet (Fig. 9a), while Millar's material from Mozambique has a short atrial languet (Millar 1962). The lateral thoracic organs are circular and not protruding, localised in the anterior half of the thorax at the level of the $1^{\text {st }}$ row of stigmata, close to the endostyle (Fig. 9b). The muscular process is longer than the abdomen, up to $1.4 \mathrm{~mm}$ in length and inserted in the middle of the esophageal peduncle. The abdomen is positioned perpendicularly to the thorax. The secondary gut loop does not overlay the stomach (Fig. 9a). The stoloniferous vessels are small and rounded, and a glandular tissue in the shape of a crescent lays inside the gut loop on the right side. The testis is slightly below the gut loop, divided in 10 to 12 follicles and surrounded by three to five coils of the sperm duct (Fig. 9c-d). The larvae are elliptical, gemmiparous and the trunk is $1.4 \mathrm{~mm}$ long. A tail with a diameter of $104 \mu \mathrm{m}$ winds halfway around the trunk. The three adhesive papillae are close to each other, with short peduncles. The sucker of the central adhesive papilla is $133 \mu \mathrm{m}$ in diameter and the peduncle is $401 \mu \mathrm{m}$ long. There are 12 to 15 elongated ectodermal ampullae on each side of the larva body, 113 to $333 \mu \mathrm{m}$ long, depending on the developmental stage of the larva (Fig. 9e). The sensorial vesicle (including ocellus and statocyte) is located in the mid-dorsal region of the larval trunk. The ocellus is $57 \mu \mathrm{m}$ long and $436 \mu \mathrm{m}$ distant from the anterior region of the tail. 


\section{Remarks}

This species was first reported from Mozambique by Millar in 1961, but the original description was published later by him in 1962 (Millar 1962) with the following diagnostic characters: short atrial languet, testis with eight to ten follicles surrounded by $2 \frac{1}{2}$ coils of the sperm duct and larva with 15 pairs of ectodermal ampullae. The sample from Madagascar has a larger atrial languet and a larger number of testis follicles and coils of the sperm duct, but the larval characters are the same. Kott (1975) synonymised it with P. aspiculatum Tokioka, 1949, but later, C. Monniot et al. (2001) confirmed that
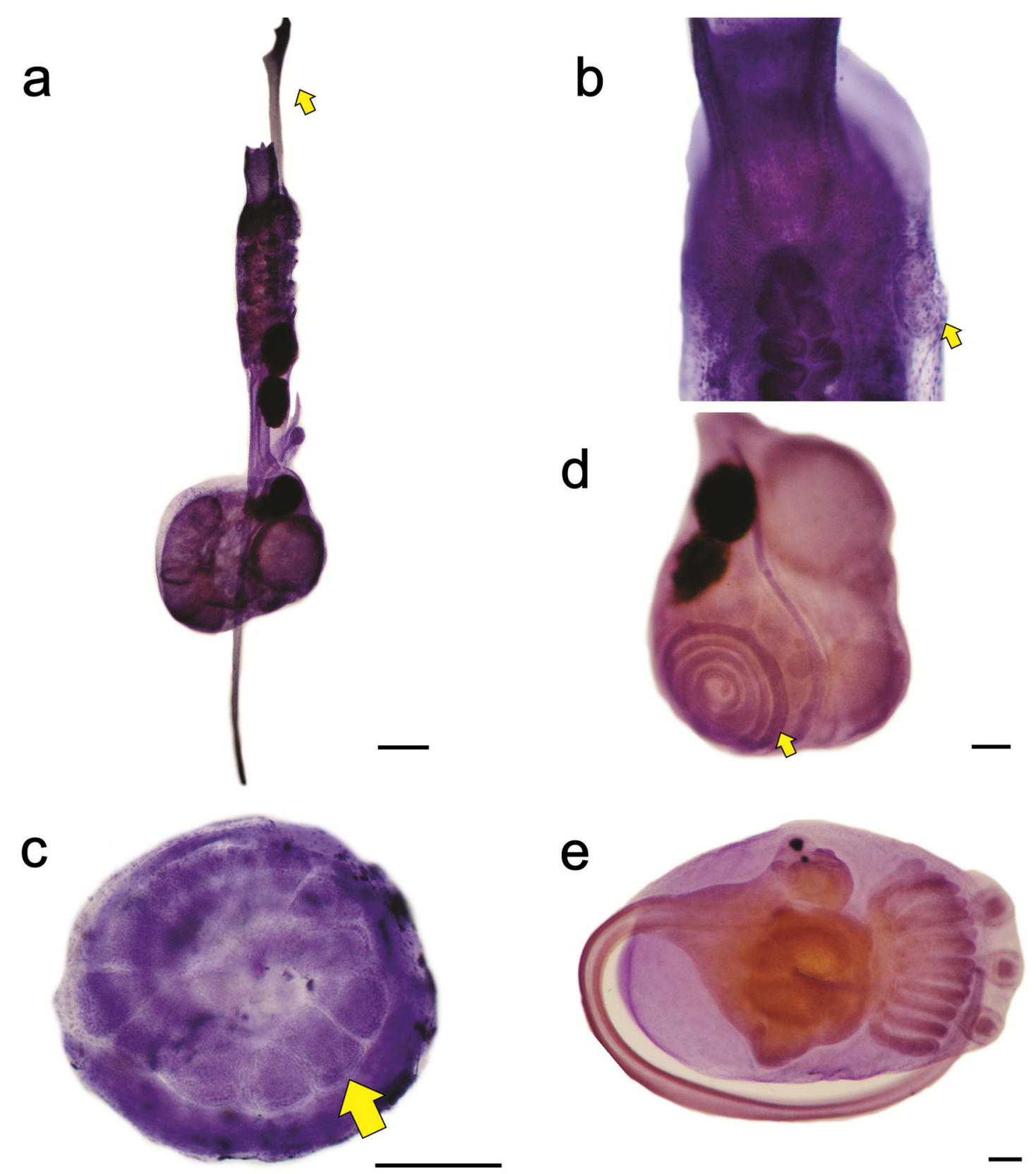

Fig. 9. Polysyncraton magnilarvum (Millar, 1962), stained with hemalum. a. Zooid (arrow pointing at atrial languet). b. Ventral view of the anterior region of the thorax (arrow indicating the lateral thoracic organ). c. Testis follicles (arrow indicating one lobe). d. Abdomen (arrow indicates the sperm duct) (MNHN A2-2466). e. Larva (MNHN A2-2467). Scale bars: a $=0.2 \mathrm{~mm}$; $\mathrm{c}-\mathrm{e}=0.1 \mathrm{~mm}$. 
both species were valid and differentiated $P$. aspiculatum by its globular spicules, the larvae with a trunk length of $1 \mathrm{~mm}$ of trunk length and eight pairs of ectodermal ampullae.

\section{Distribution}

Type locality: Mozambique (Millar 1962). South Madagascar (this study).

Polysyncraton purou C. Monniot \& F. Monniot, 1987

Fig. 10

Polysyncraton purou C. Monniot \& F. Monniot, 1987: 49, fig. 16d-h, pl. 3 i.

Polysyncraton purou -F. Monniot 1993: 11. — Kott 2001: 126, figs 60, 162C, pl. 6F; 2002: 33, fig. 12AD; 2005: 2436, fig. 19D.

\section{Material examined}

TANZANIA • 3 slides; MNHN A2-843, MNHN A2-846, MNHN A2-847.

\section{Remarks}

This species was described from French Polynesia by C. Monniot \& F. Monniot (1987). All the characteristics of the specimens from Tanzania correspond to those in the original description (Fig. 10), thus enlarging the known distribution of this species.

Monniot \& Monniot (2001) described P. vestiens from Palau as a different species from $P$. purou based on the smaller spicules, a wider atrial aperture and the absence of the muscular process in $P$. vestiens. However, in the specimens from Tanzania there is a variation in the size of the spicules and they are smaller $(43$ to $55 \mu \mathrm{m})$ than in specimens from Tahiti. The muscular process in P. purou is very small and not visible in some zooids (Fig. 10a-b). Since the size of the atrial aperture is also a variable character that depends on the contraction of the zooid, there is doubt as to whether $P$. vestiens is a valid species.

\section{Distribution}

Type locality: French Polynesia (C. Monniot \& F. Monniot 1987). Australia (Kott 2001), New Caledonia (F. Monniot 1993) and Tanzania (this study).

Polysyncraton snelliusi Oliveira \& Rocha sp. nov. urn:1sid:zoobank.org:act:650A74FA-077A-46B4-B1EF-9BF5CC2B44E6

Fig. 11

\section{Etymology}

The name refers to the campaign vessel that collected the material.

\section{Material examined}

Holotype

SURINAME • 1 colony; Guiana Shelf, stat. 97; 07¹6.8' N, 56²4.6' W; 64 m depth; 13 Apr. 1966; HNLMS Snellius leg.; Onderzoek Continentaal Plat Suriname (OCPS); RMNH.UROCH.1109.

\section{Description}

The colony is yellowish in preserved material, measuring $8 \mathrm{~cm}$ in diameter and $2 \mathrm{~mm}$ thick. It has an irregular shape, molding itself on top of a sponge. The colony surface has several common cloacal apertures with six to eight short lobes each (Fig. 11b). The cloacal cavity is wide and positioned at the 
a
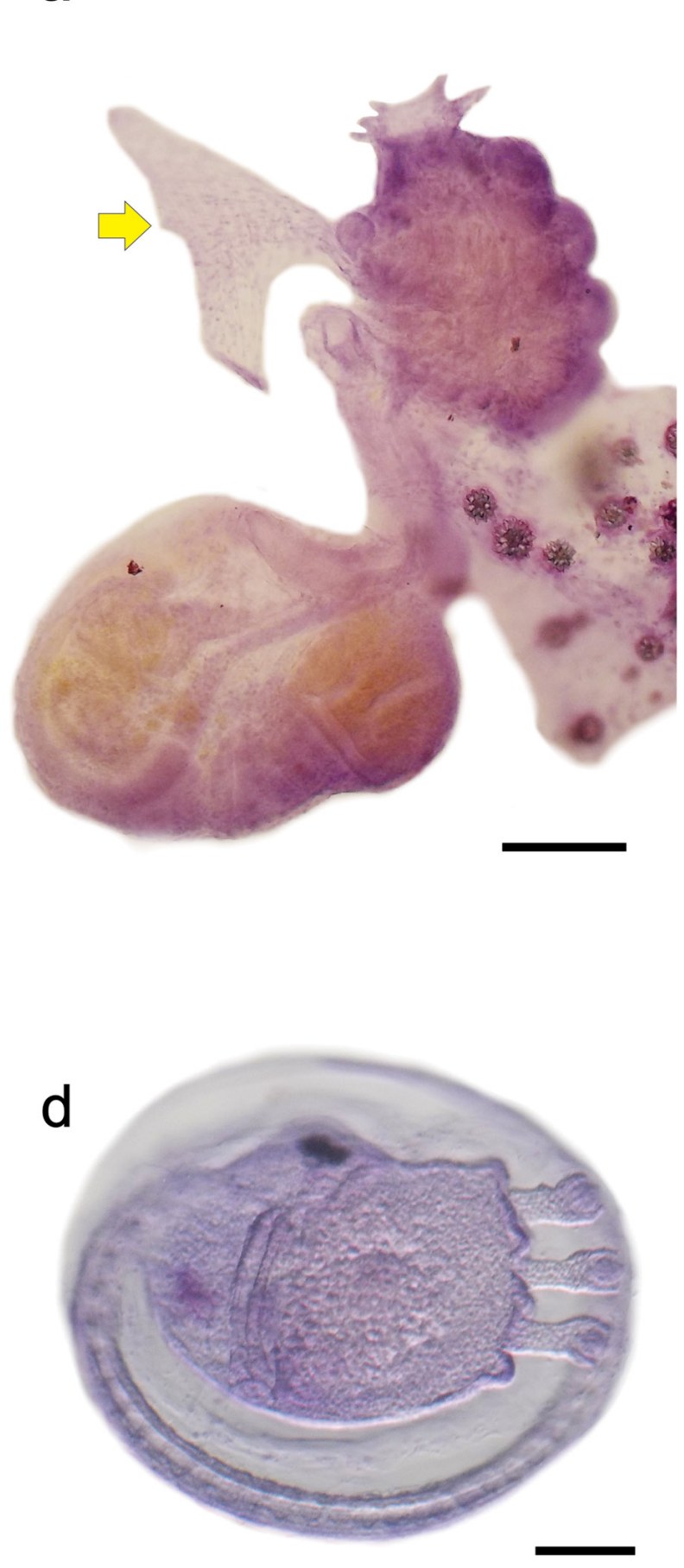

b

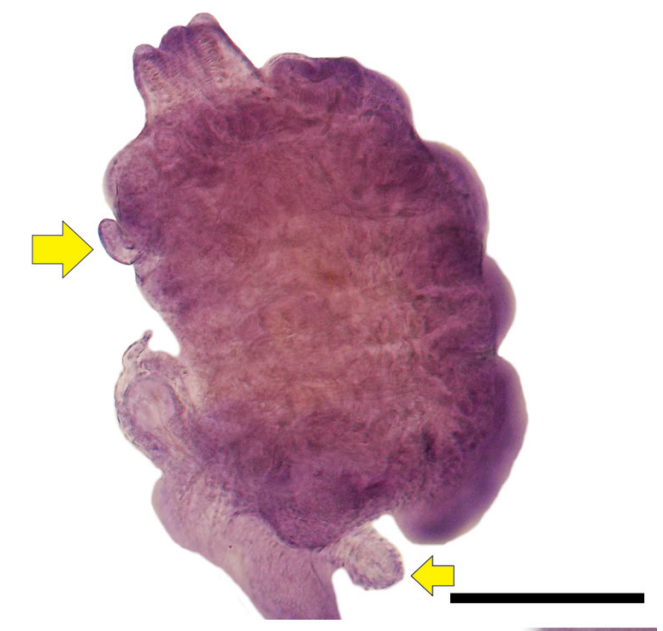

C
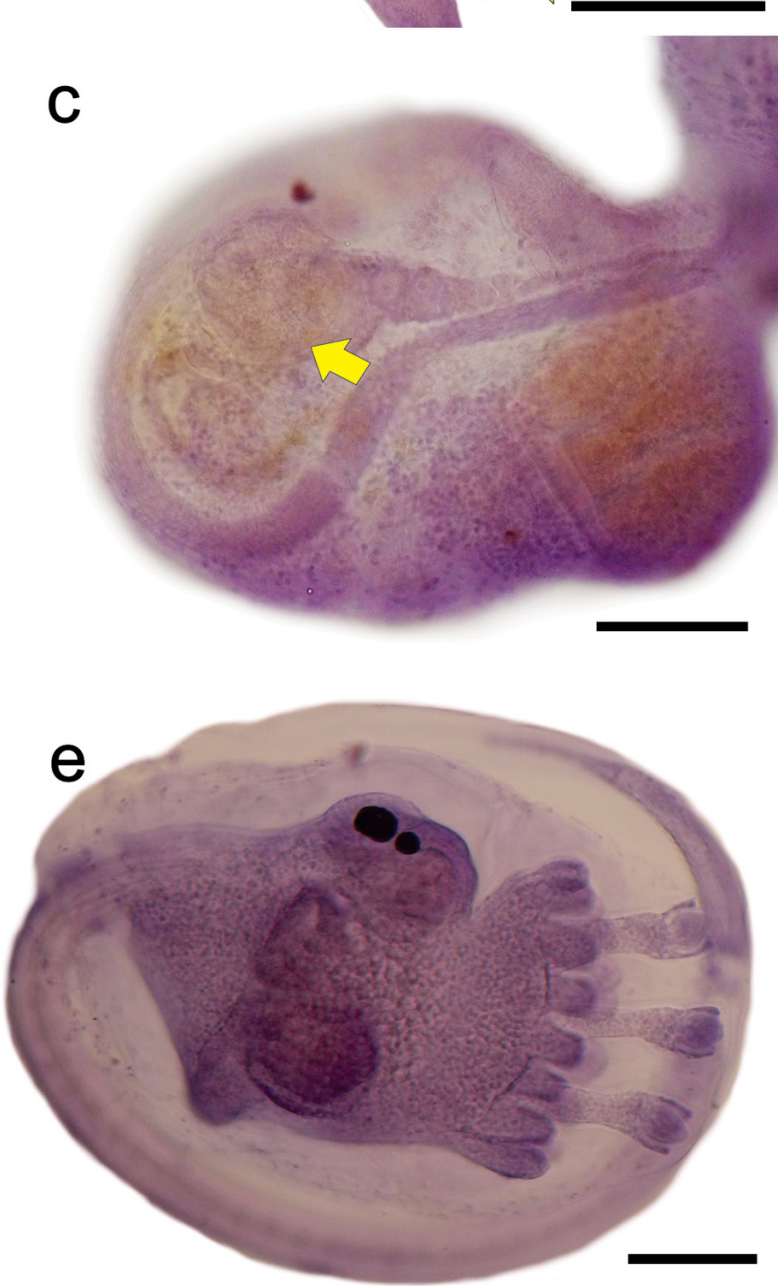

Fig. 10. Polysyncraton purou C. Monniot \& F. Monniot, 1987, with structures stained with hemalum (MNHN A2-843). a. Zooid with bifurcated atrial languet (arrow). b. Thorax with button-like atrial languet (big arrow) and muscular process (small arrow). c. Abdomen with gonads (large arrow indicates oocyte). d. Immature larva. e. Mature larva. Scale bar: $0.1 \mathrm{~mm}$. 
thoracic level. The tunic is firm, brittle and with many papillae associated with one of the lobes of the oral siphons. The zooids form circular systems around the cloaca and also linear systems along the cloacal channels, which are marked by a depression on the colony surface. They have a brown colour, leaving white circular or irregular patches on the colony surface (Fig. 11c). Two types of stellate spicules are distributed in the tunic. The larger ones ( 40 to $60 \mu \mathrm{m}$ in diameter) have six rays in transverse optical section, but many other shorter rays among the main ones. Also, the rays are either blunt or more pointed. The smaller spicules ( 23 to $50 \mu \mathrm{m}$ in diameter, a few to $60 \mu \mathrm{m}$ ), have seven to eight conical rays with round tips in transverse optical section, without intermediate rays (Fig. 11d).

The zooids are $1.0 \mathrm{~mm}$ long. The oral siphon is short $(0.2 \mathrm{~mm})$, with six long triangular lobes. The atrial aperture is wide, exposing almost all the pharynx, without an atrial languet. The pharynx stigmata formula is $12,12,11,9$. The lateral thoracic organs are circular, not protruding and localised at the level of the $2^{\text {nd }}$ row of stigmata. The muscular process is lacking. The esophageal peduncle is short and straight. The testis is divided in four follicles surrounded by three coils of the sperm duct. The secondary gut loop does not overlay the stomach (Fig. 11e).

The larvae are elliptical, not gemmiparous, with the trunk 0.8 to $0.9 \mathrm{~mm}$ long. A tail with a diameter of $116 \mu \mathrm{m}$ winds halfway around the trunk. The sucker of the central adhesive papilla is $95 \mu \mathrm{m}$ in diameter and the peduncle is $235 \mu \mathrm{m}$ long. There are 12 to 14 elongated, thin ectodermal ampullae on each side of the larva, 105 to $120 \mu \mathrm{m}$ long (Fig. 11f). The sensorial vesicle (including ocellus and statocyte) is slightly posterior to the mid-dorsal region of the larval trunk. The ocellus is $54 \mu \mathrm{m}$ long and $361 \mu \mathrm{m}$ distant from the anterior region of the tail.

\section{Remarks}

Eight species of Polysyncraton have been reported from the Atlantic Ocean (Rocha et al. 2012; Paiva et al. 2015) and none of them look like the one described herein. Polysyncraton snelliusi sp. nov. can be distinguished from P. cabofriense sp. nov. by the absence of papillae on the colony surface and the presence of gemmiparous larvae in the latter. Among other species with papillae on the colony surface, P. echinatum Kott, 2001 has a gelatinous tunic, stellate spicules without secondary rays and smaller larvae (trunk $0.6 \mathrm{~mm}$ long), with four subdividing ectodermal ampullae on each side; P. meandratum F. Monniot, 1993 has globular spicules with flat-tipped rays, a bifurcated atrial languet and larvae with eight pairs of ectodermal ampullae; P. pseudorugosum F. Monniot, 1993 has stellate spicules with sharp pointed rays and deeper common cloacal canals, seven testis follicles and smaller larvae with eight pairs of ectodermal ampullae.

\section{Distribution}

Type locality: Suriname (Guyana Shelf).

\section{Polysyncraton sp.}

Fig. 12

\section{Material examined}

BRAZIL • 1 colony; Rio de Janeiro, Cabo Frio, Pargos Island, Enseada do Pinguim; 22 $51^{\prime} 10^{\prime \prime}$ S, 415'2" W; 10 m depth; 7 May 2014; L.F. Skinner leg.; DZUP POSC-033, slide DZUP DID5.29.

\section{Remarks}

The colony is orange in situ, measuring $3 \mathrm{~cm}$ in diameter and 1 to $2 \mathrm{~mm}$ thick. The tunic is firm and gelatinous. The cloacal aperture has five lobes. The spicules are distributed in the colony surface only and are more concentrated around the oral siphon of each zooid. They are burr-like, with a large number 

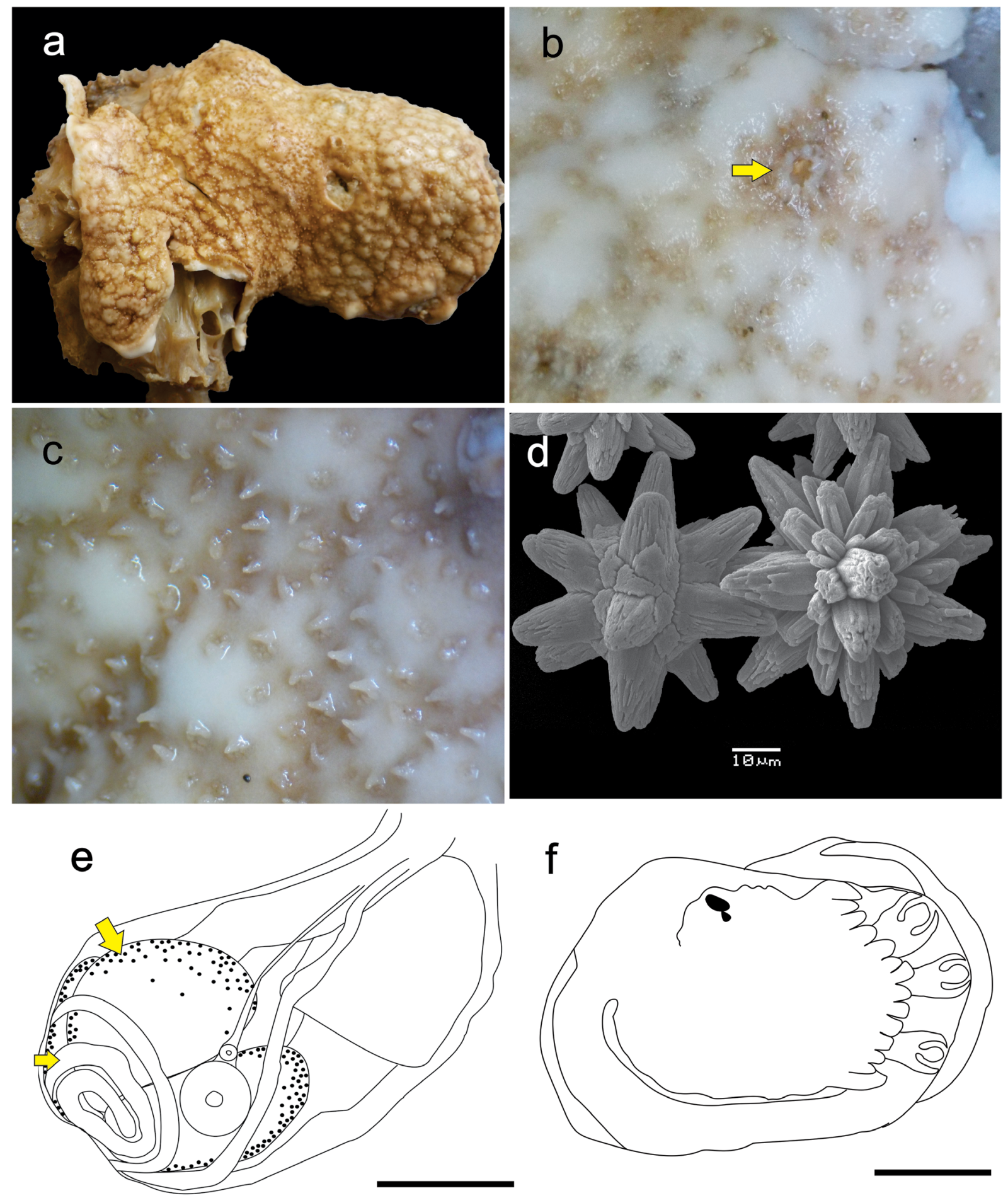

Fig. 11. Polysyncraton snelliusi Oliveira \& Rocha sp. nov. a. Preserved colony. b. Colony surface (arrow indicates the common cloacal aperture with lobes). c. Papillae on the colony surface. d. Spicules (large type). e. Abdomen with gonads, large arrow indicates the follicle (one follicle hidden) and the small arrow the sperm duct. f. Larva. Scale bars: $\mathrm{e}-\mathrm{f}=0.2 \mathrm{~mm}$. 
of rays, 15 to $25 \mu \mathrm{m}$ in diameter. The zooids are orange. The oral siphon is short, with six triangular lobes. The atrial aperture is wide, exposing almost all the pharynx, with 9, 9, 8, 8-7 stigmata per half row. The atrial languet is large and bifurcated. The lateral thoracic organ is circular, not protruding, located at the level of the $1^{\text {st }}$ row of stigmata. The muscular process is shorter than the abdomen, inserted in the middle of the esophageal peduncle. The testis is divided in four follicles surrounded by four coils of the sperm duct. Larvae were not found.

In the phylogenetic reconstruction (Fig. 5), this species (UPDID096-17) is separate from P. amethysteum, from which it differs by the colour of the colony, lobed cloaca and the position of the lateral thoracic organ. Lotufo (2002) reported orange specimens from Rio de Janeiro and Espírito Santo, but we were able to examine the sample from Angra dos Reis and concluded that Lotufo's sample (ColBio Tun 1245) actually belongs to the genus Leptoclinides Bjerkan, 1905.

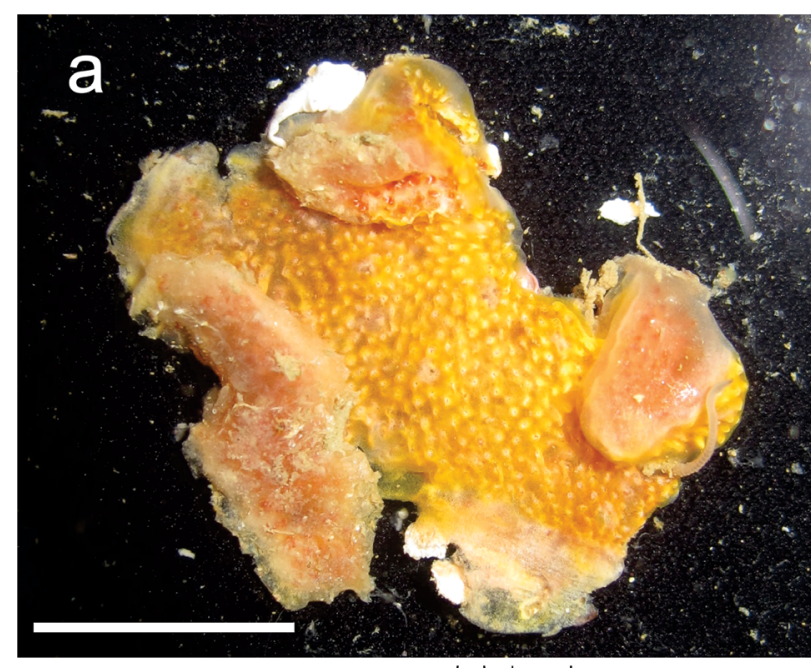

b
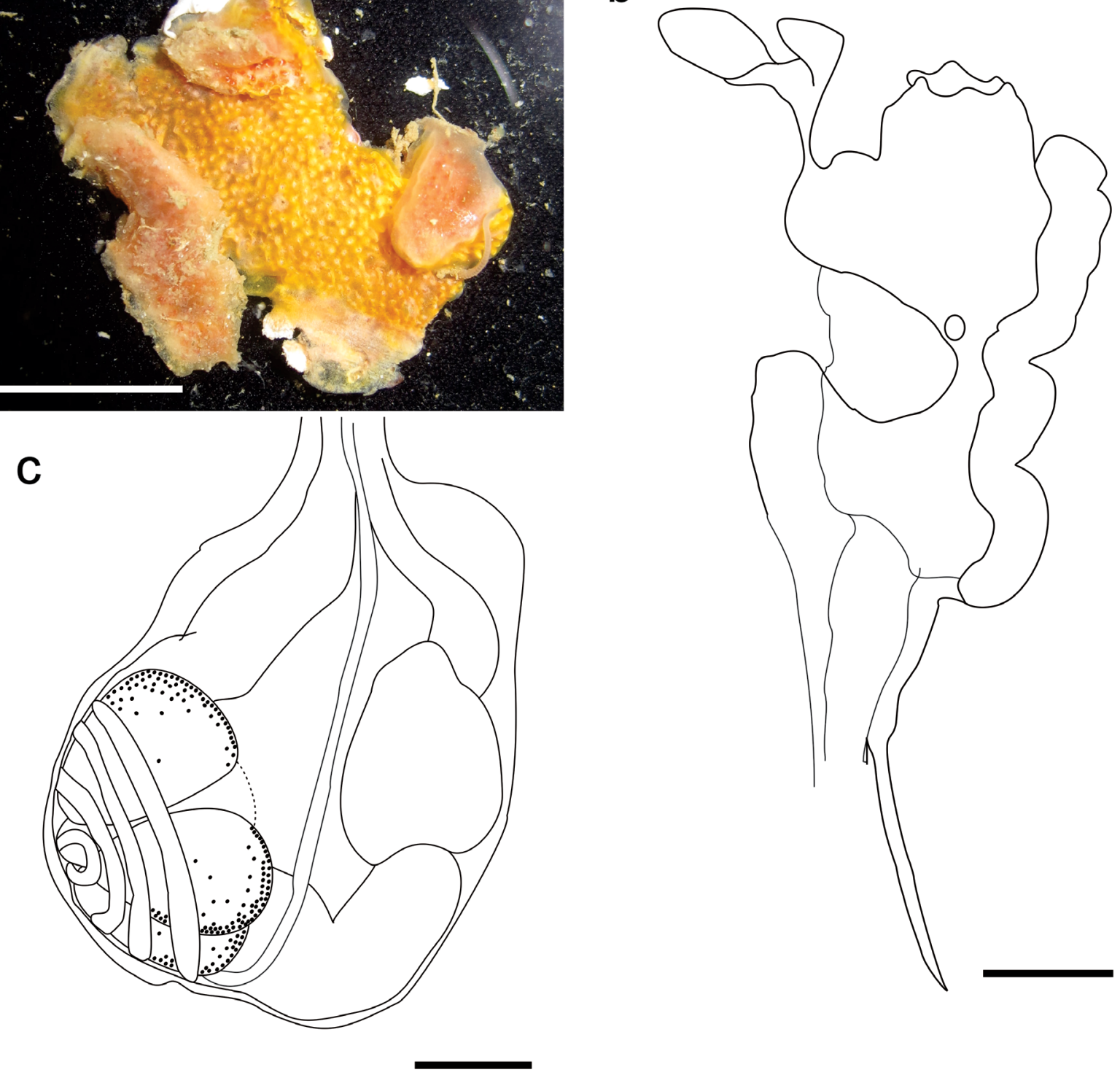

Fig. 12. Polysyncraton sp. a. Preserved colony. b. Thorax. c. Abdomen. Scale bars: $a=1 \mathrm{~cm} ; \mathrm{b}-\mathrm{c}=$ $0.1 \mathrm{~mm}$. 
This species differs from $P$. cabofriense sp. nov., by the colour of the colony, the abundance, shape and position of the spicules, and in having more follicles and coils of the sperm duct. Given the single colony found and lack of larvae we prefer not to name it, although characters suggest that it is an undescribed species.

\section{Distribution}

Brazil: Rio de Janeiro (this study).

\section{Discussion}

Didemnidae is one of the largest families in Ascidiacea and its interspecific differentiation is usually achieved by the combination of characters, among which larval characters are usually very important. For Polysyncraton, the spicule density, distribution, shape and size, the size of the lateral organ, the number of testicular follicles and coils of the sperm duct, the size of the larva, the gemmiparous condition and the number of ectodermal ampullae are known as the most important characters to differentiate species (Kott 1962; F. Monniot 1984). We have also observed specific differences in the colour and shape of the colony (sheet-like or globose) and the cloaca rim (smooth or lobed).

Unfortunately, formalin fixation is routine in protocols of ascidian preservation (C. Monniot \& F. Monniot 1972), even though samples are maintained in ethanol for long term preservation in museum collections. Thus, genetic studies are only possible with samples specifically collected for this purpose and we were only able to use genetic evidence to delimit species from samples recently collected along the Brazilian coast. This genetic study was useful to demonstrate that $P$. amethysteum has a large distribution range along the West Atlantic and the Gulf of Mexico, with a lot of variation in colour, spicule density, number of testicular follicles and sperm duct coils, and larva size.

Most of the diversification in Polysyncraton is found in the Indo-Pacific, with Australia being the beststudied country (Kott 2001). Genetic studies with the goal to understand the evolution of this genus will have to focus on the biodiversity in this region. Even though the Pacific is the most species-rich region, we were able to identify a new species (Polysyncraton globosum sp. nov.) from Australia, which has almost $45 \%$ of all Polysyncraton species currently known.

Considering that only three species of Polysyncraton were previously known from the tropical West Atlantic (P. amethysteum, P. louminae and P. maurizelae), the two new species from this region here described, and another possibly undescribed species, represent a significant contribution. It is important to also emphasize that sampling efforts in the West Atlantic and Gulf of Mexico are still not comprehensive and other species are expected to be discovered.

\section{Acknowledgments}

We would like to thank Françoise Monniot and Tito Lotufo for allowing us to borrow samples, Luis Felipe Skinner for his help during the field work and Miranda Lowe, Linda Cole and Estefanía Rodriguez for receiving LMO at the NHM, USNM and AMNH. Naturalis Biodiversity Center offered logistical support. CNPq (141490/2014-4, 201086/2015-SWE, 445783/2014-1) financed part of this project, and the National Science Foundation (DEB-1456674) financed LMO's visit to the American collections.

\section{References}

Goodbody I. 2000. Diversity and distribution of ascidians (Tunicata) in the Pelican Cays, Belize. Atoll Research Bulletin 480: 303-333. Available from https://repository.si.edu/handle/10088/5860 [accessed 20 Mar. 2019]. 
OLIVEIRA L.M. et al., Re-examination of specimens and three new species of Polysyncraton

Gravier R. 1955. Ascidies récoltées par le « Président Théodore Tissier » (Campagne de Printemps 1951). Revue des Travaux de l'Institut des Pêches maritimes 19: 611-631.

Hartmeyer R. 1912. Die Ascidien der Deutschen Tiefsee-Expedition. Deutsche Tiefsee-Expedition 16: 225-392.

Hastings A.B. 1931. Tunicata. Great Barrier Reef Expedition 1928-29. Scientific Reports 4: 69-110. Available from https://biodiversitylibrary.org/page/49516617 [accessed 20 Jul. 2018].

Kott P. 1962. The ascidians of Australia. 3. Aplousobranchiata Lahille: Didemnidae Giard. Australian Journal of Marine and Freshwater Research 13 (3): 265-334.

Kott P. 1975. The Ascidians of South Australia. III. Northern Sector of the Great Australian Bight and additional records. Transactions of the Royal Society of South Australia 99 (1): 1-20.

Available from https://biodiversitylibrary.org/page/41070575 [accessed 20 Jul. 2018].

Kott P. 2001. The Australian Ascidiacea. Part 4, Aplousobranchia (3), Didemnidae. Memoirs of the Queensland Museum 47 (1): 1-410.

Available from https://biodiversitylibrary.org/page/40460926 [accessed 20 Jul. 2018].

Kott P. 2002. Ascidiacea (Tunicata) from Darwin, Northern Territory, Australia. The Beagle: Records of the Museums and Art Galleries of the Northern Territory 18: 19-55.

Kott P. 2005. Ascidians from the Solomon Islands. The Beagle: Records of the Museums and Art Galleries of the Northern Territory 21: 53-66.

Lotufo T.M.C. 2002. Ascidiacea (Chordata: Tunicata) do litoral tropical brasileiro. PhD Thesis. Instituto de Biociências da Universidade de São Paulo, Brazil.

Lotufo T.M.C. \& Silva A.M.B. 2006. Ascidiacea do litoral Cearense. In: Matthews-Cascon H. \& Lotufo T.M.C. (eds) Biota marinha da Costa Oeste do Ceará: 221-247. Série Biodiversidade 24, Ministério do Meio Ambiente, Fortaleza, Brazil.

Millar R.H. 1953. On a collection of ascidians from the Gold Coast. Proceedings of the Zoological Society of London 123 (2): 277-325. https://doi.org/10.1111/j.1096-3642.1953.tb00176.x

Millar R.H. 1958. Some ascidians from Brazil. Annals and Magazine of Natural History 1: 497-514. https://doi.org/10.1080/00222935808650975

Millar R.H. 1962. Further descriptions of South African ascidians. Annals of the South African Museum 46 (7): 113-196.

Millar R.H. 1963. Australian ascidians in the British Museum (Natural History). Proceedings of the Zoological Society of London 141 (4): 689-746. https://doi.org/10.1111/j.1469-7998.1963.tb01623.x

Millar R.H. 1977. Ascidians (Tunicata: Ascidiacea) from the northern and north-eastern Brazilian shelf. Journal of Natural History 11: 169-223. https://doi.org/10.1080/00222937700770131

Miller M.A., Pfeiffer W. \& Schwartz T. 2010. Creating the CIPRES Science Gateway for Inference of Large Phylogenetic Trees. Gateway Computing Environments Workshop, New Orleans.

https://doi.org/10.1109/GCE.2010.5676129

Monniot C. \& Monniot F. 1967. Tuniciers benthiques. Annales de l'Institut océanographique 2: 1-18.

Monniot C. \& Monniot F. 1972. Clé mondiale des genres d'ascidies. Archives de Zoologie expérimentale et générale 113: 311-367.

Monniot C. \& Monniot F. 1987. Les ascidies de Polynésie française. Mémoires du Muséum national d'Histoire naturelle, Zoologie 136: 1-155. 
Monniot C., Monniot F. \& Laboute P. 1991. Coral Reef Ascidians of New Caledonia. Editions de l'ORSTOM 30, Muséum national d'Histoire naturelle, Paris.

Monniot C., Monniot F., Griffiths C.L. \& Schleyer M. 2001. South African ascidians. Annals of the South African Museum 108 (1): 1-141.

Available from https://biodiversitylibrary.org/page/40905473 [accessed 20 Jul. 2018].

Monniot F. 1984. Ascidies littorales de Guadeloupe VIII. Questions de systématique évolutive posées par les Didemnidae. Bulletin du Muséum national d'Histoire naturelle, $4^{\text {ième }}$ série 6 $6^{\mathrm{a}}$ (4): 885-905.

Monniot F. 1993. Ascidies de Nouvelle-Calédonie XIII. Le genre Polysyncraton. Bulletin du Muséum national d'Histoire naturelle, $4^{\text {ième }}$ série $15^{\text {a }}(1-4)$ : 3-17.

Monniot F. 2016. Ascidians (Tunicata) of the French Guiana Expedition. Zootaxa 4114 (3): 201-245. https://doi.org/10.11646/zootaxa.4114.3.1

Monniot F. \& Monniot C. 2001. Ascidians from the tropical western Pacific. Zoosystema 23 (2): 201383.

Moure J.S., Björnberg T.K.S \& Loureiro T.S. 1954. Protochordata ocorrentes na entrada da Baía de Paranaguá. Dusenia 5: 233-242.

Oliveira F.A.S., Michonneau F. \& Lotufo T.M.C. 2017. Molecular phylogeny of Didemnidae (Ascidiacea: Tunicata). Zoological Journal of the Linnean Society 20: 1-10.

https://doi.org/10.1093/zoolinnean/zlw002

Paiva S.V., Oliveira-Filho R.R. \& Lotufo T.M.C. 2015. Ascidians from Rocas Atoll, northeast Brazil. Frontiers in Marine Science 2: 1-20. https://doi.org/10.3389/fmars.2015.00039

Pérès J.M. 1948. Note sur deux espèces d'ascidies du Gulf de Marseille. Bulletin du Musée d'Histoire naturelle de Marseille 8 (2-3): 54-61.

Pérès J.M. 1949.Contribution à l'étude des ascidies de la côte occidentale d'Afrique. Bulletin de l'Institut français d'Afrique noire 11 (1-2): 159-207.

Rambaut A. 2014. Figtree: Tree Figure Drawing Tool Version 1.4.2. Institute of Evolutionary Biology, University of Edinburg. Available from http://tree.bio.ed.ac.uk/software/figtree/ [accessed 20 Jul. 2018].

Rocha R.M., Moreno T.R. \& Metri R. 2005. Ascídias (Tunicata, Ascidiacea) da Reserva Biológica Marinha do Arvoredo, Santa Catarina, Brasil. Revista Brasileira de Zoologia 22: 461-476.

Rocha R.M., Zanata T.B. \& Moreno T.R. 2012. Keys for the identification of families and genera of Atlantic shallow water ascidians. Biota Neotropica 12: 269-303.

https://doi.org/10.1590/S1676-06032012000100022

Rodrigues S.A. 1962. Algumas ascidias do litoral sul do Brasil. Boletim da Faculdade de Filosofia, Ciências e Letras, Universidade de São Paulo 24: 193-216.

Ronquist F., Teslenko M., Van Der Mark P., Ayres D.L., Darling A., Höhna S., Larget B., Liu L., Suchard M.A. \& Huelsenbeck J.P. 2012. MrBayes 3.2: Efficient bayesian phylogenetic inference and model choice across a large model space. Systematic Biology 61 (3): 539-542. https://doi.org/10.1093/sysbio/sys029

Sluiter C.P. 1909. Die Tunicaten der Siboga Expedition. Pt II. Die merosomen Ascidien. SibogaExpeditie 56B: 1-112.

Stamatakis A. 2006. Phylogenetic models of rate heterogeneity: a high performance computing perspective. Proceedings of the $20^{\text {th }}$ IEEE/ACM International Parallel and Distributed Processing Symposium (IPDPS 2006). Rhodos, Greece. 
Stamatakis A. 2014. RAxML version 8: A tool for phylogenetic analysis and post-analysis of large phylogenies. Bioinformatics 30: 1312-1313. https://doi.org/10.1093/bioinformatics/btu033

Stefaniak L., Lambert G., Gittenberger A., Zhang H., Lin S. \& Whitlatch R.B. 2009. Genetic conspecificity of the worldwide populations of Didemnum vexillum Kott, 2002. Aquatic Invasions 4: 29-44. https://doi.org/10.3391/ai.2009.4.1.3

Van Name W.G. 1902. The Ascidians of the Bermuda Islands. Transactions of the Connecticut Academy of Arts and Sciences 11: 325-412. Available from https://www.biodiversitylibrary.org/page/13464308 [accessed 20 Jul. 2018].

Van Name W.G. 1921. Ascidians of the West Indian region and south eastern United States. Bulletin of the American Museum of Natural History 44: 283-494.

Van Name W.G. 1945. The North and South American ascidians. Bulletin of the American Museum of Natural History 84: 1-476.

Manuscript received: 26 July 2018

Manuscript accepted: 18 January 2019

Published on: 23 April 2019

Topic editor: Rudy Jocqué

Desk editor: Kristiaan Hoedemakers

Printed versions of all papers are also deposited in the libraries of the institutes that are members of the EJT consortium: Muséum national d'Histoire naturelle, Paris, France; Meise Botanic Garden, Belgium; Royal Museum for Central Africa, Tervuren, Belgium; Royal Belgian Institute of Natural Sciences, Brussels, Belgium; Natural History Museum of Denmark, Copenhagen, Denmark; Naturalis Biodiversity Center, Leiden, the Netherlands; Museo Nacional de Ciencias Naturales-CSIC, Madrid, Spain; Real Jardín Botánico de Madrid CSIC, Spain; Zoological Research Museum Alexander Koenig, Bonn, Germany. 